Cochrane Database of Systematic Reviews

\title{
Fluid therapy for acute bacterial meningitis (Review)
}

Maconochie IK, Bhaumik S

Maconochie IK, Bhaumik S.

Fluid therapy for acute bacterial meningitis.

Cochrane Database of Systematic Reviews 2016, Issue 11. Art. No.: CD004786.

DOI: 10.1002/14651858.CD004786.pub5.

www.cochranelibrary.com 
TABLE OF CONTENTS

HEADER 1

ABSTRACT

PLAIN LANGUAGE SUMMARY

SUMMARY OF FINDINGS

BACKGROUND

OBJECTIVES

METHODS

RESULTS

Figure 1.

Figure 2.

DISCUSSION

AUTHORS' CONCLUSIONS

ACKNOWLEDGEMENTS

REFERENCES

CHARACTERISTICS OF STUDIES

DATA AND ANALYSES

Analysis 1.1. Comparison 1 Maintenance fluids versus restricted fluids, Outcome 1 Death.

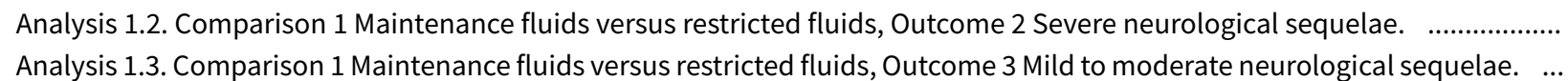

Analysis 1.4. Comparison 1 Maintenance fluids versus restricted fluids, Outcome 4 Hemiparesis/hemiplegia.

Analysis 1.5. Comparison 1 Maintenance fluids versus restricted fluids, Outcome 5 Spasticity.

Analysis 1.6. Comparison 1 Maintenance fluids versus restricted fluids, Outcome 6 Seizures.

Analysis 1.7. Comparison 1 Maintenance fluids versus restricted fluids, Outcome 7 Visual impairment.

Analysis 1.8. Comparison 1 Maintenance fluids versus restricted fluids, Outcome 8 No response to sound.

Analysis 1.9. Comparison 1 Maintenance fluids versus restricted fluids, Outcome 9 Oedema.

Analysis 1.10. Comparison 1 Maintenance fluids versus restricted fluids, Outcome 10 Total body water - fall after 48 hours. ....

Analysis 1.11. Comparison 1 Maintenance fluids versus restricted fluids, Outcome 11 Extracellular water - fall after 48 hours. ....

Analysis 1.12. Comparison 1 Maintenance fluids versus restricted fluids, Outcome 12 Serum sodium.

Analysis 1.13. Comparison 1 Maintenance fluids versus restricted fluids, Outcome 13 Urinary sodium.

Analysis 1.14. Comparison 1 Maintenance fluids versus restricted fluids, Outcome 14 Plasma osmolality - change after 48 hours.

APPENDICES

FEEDBACK

WHAT'S NEW

HISTORY

CONTRIBUTIONS OF AUTHORS

DECLARATIONS OF INTEREST

SOURCES OF SUPPORT

DIFFERENCES BETWEEN PROTOCOL AND REVIEW

INDEX TERMS 
[Intervention Review]

\section{Fluid therapy for acute bacterial meningitis}

Ian K Maconochie ${ }^{1}$, Soumyadeep Bhaumik ${ }^{2}$

1Department of Paediatrics A\&E, St Mary's Hospital, London, UK. 2Department of International Public Health, Liverpool School of Tropical Medicine, Liverpool, UK

Contact address: Ian K Maconochie, Department of Paediatrics A\&E, St Mary's Hospital, South Wharf Road, Paddington, London, WC2 1NY, UK. i.maconochie@ic.ac.uk.

Editorial group: Cochrane Acute Respiratory Infections Group.

Publication status and date: New search for studies and content updated (conclusions changed), published in Issue 11, 2016.

Citation: Maconochie IK, Bhaumik S. Fluid therapy for acute bacterial meningitis. Cochrane Database of Systematic Reviews 2016, Issue 11. Art. No.: CD004786. DOI: 10.1002/14651858.CD004786.pub5.

Copyright (c) 2016 The Cochrane Collaboration. Published by John Wiley \& Sons, Ltd.

\section{A B S T R A C T}

\section{Background}

Acute bacterial meningitis remains a disease with high mortality and morbidity rates. However, with prompt and adequate antimicrobial and supportive treatment, the chances for survival have improved, especially among infants and children. Careful management of fluid and electrolyte balance is an important supportive therapy. Both over- and under-hydration are associated with adverse outcomes. This is the latest update of a review first published in 2005 and updated in 2008 and 2014.

\section{Objectives}

To evaluate treatment of acute bacterial meningitis with differing volumes of initial fluid administration (up to 72 hours after first presentation) and the effects on death and neurological sequelae.

\section{Search methods}

For this 2016 update we searched the following databases up to March 2016: the Cochrane Acute Respiratory Infections Group's Specialised Register, CENTRAL, MEDLINE, CINAHL, Global Health, and Web of Science.

\section{Selection criteria}

Randomised controlled trials (RCTs) of differing volumes of fluid given in the initial management of bacterial meningitis were eligible for inclusion.

\section{Data collection and analysis}

All four of the original review authors extracted data and assessed trials for quality in the first publication of this review (one author, ROW, has passed away since the original review; see Acknowledgements). The current authors combined data for meta-analysis using risk ratios (RRs) for dichotomous data or mean difference (MD) for continuous data. We used a fixed-effect statistical model. We assessed the overall quality of evidence using the GRADE approach.

\section{Main results}

We included three trials with a total of 420 children; there were no trials in adult populations. The largest of the three trials was conducted in settings with high mortality rates and was judged to have low risk of bias for all domains, except performance bias which was high risk. The other two smaller trials were not of high quality.The meta-analysis found no significant difference between the maintenance-fluid and restricted-fluid groups in number of deaths (RR $0.82,95 \%$ confidence interval ( $\mathrm{Cl}$ ) 0.53 to 1.27; 407 participants; low quality of evidence) or acute severe neurological sequelae (RR $0.67,95 \% \mathrm{Cl} 0.41$ to $1.08 ; 407$ participants; low quality of evidence). However, when neurological sequelae were defined further, there was a statistically significant difference in favour of the maintenance-fluid group for spasticity (RR $0.50,95 \% \mathrm{Cl} 0.27$ to $0.93 ; 357$ participants); and seizures at both 72 hours (RR 0.59, 95\% Cl 0.42 to 0.83 ; 357 participants) and 14 days (RR 
$0.19,95 \% \mathrm{Cl} 0.04$ to $0.88 ; 357$ participants). There was very low quality of evidence favouring maintenance fluid over restrictive fluid for chronic severe neurological sequelae at three months follow-up (RR $0.42,95 \% \mathrm{Cl} 0.20$ to $0.89 ; 351$ participants).

\section{Authors' conclusions}

The quality of evidence regarding fluid therapy in children with acute bacterial meningitis is low to very low and more RCTs need to be conducted. There is insufficient evidence to guide practice as to whether maintenance fluids should be chosen over restricted fluids in the treatment of acute bacterial meningitis.

\section{PLAIN LANGUAGE SUMMARY}

\section{Fluids for people with acute bacterial meningitis}

\section{Review question}

Why is the effect of differing volumes of initial fluid administration on death and various neurological sequelae in people with acute bacterial meningitis important?

\section{Background}

Bacterial meningitis is an infection of the fluid in the spinal cord and surrounding the brain. Antibiotics are prescribed as treatment. Supportive care includes other drugs and the regulation of fluid intake. There has been disagreement about whether fluids should be restricted or unrestricted as there are potential risks from giving too much fluid (brain swelling) as well as too little fluid (shock).

\section{Study characteristics}

The evidence is current to March 2016. We did not find any trials in adult populations and included three trials involving 420 children. All trials were set in countries where death rates for meningitis are high. In one study no funding source was mentioned. The remaining two studies were funded jointly by pharmaceutical concerns with government agencies and a charitable agency.

\section{Key results}

No studies reported important healthcare outcomes such as duration of hospital stay, raised intracranial pressure, or status epilepticus. An adverse effect in children with restricted fluid intake was that they were less likely to have low levels of sodium in their blood and therefore they would experience greater reductions in body fluids. An adverse effect of unrestricted fluid administration was reported in one study as short-term swelling of the face and low blood sodium levels one to two days after fluids were started, although the largest study found no difference in blood sodium levels.

The review found limited evidence from these trials in support of not restricting fluids in settings with high mortality rates. There is no evidence to guide clinicians about fluid therapy in adult patients with acute bacterial meningitis. There is a need for more research on these aspects in the future.

\section{Quality of the evidence}

Analysis of available trials found low quality evidence that there is no significant difference between maintenance versus restrictive fluid regimens for the outcome of death and acute severe neurological complications. There was also some evidence favouring maintenance fluid therapy over restricted fluids for chronic severe neurological events at three months follow-up, but the quality was very low. 


\begin{tabular}{|c|c|c|c|c|c|}
\hline \multicolumn{6}{|c|}{$\begin{array}{l}\text { S U M M A R Y O F F I N D I N G S } \\
\text { Summary of findings for the main comparison. Maintenance fluids versus restricted fluids for acute bacterial meningitis }\end{array}$} \\
\hline \multicolumn{6}{|c|}{ Maintenance fluids versus restricted fluids for acute bacterial meningitis } \\
\hline \multicolumn{6}{|c|}{ Patient or population: paediatric patients with acute bacterial meningitis } \\
\hline \multicolumn{6}{|c|}{ Settings: hospital inpatient department } \\
\hline \multicolumn{6}{|c|}{ Intervention: maintenance fluids } \\
\hline \multicolumn{6}{|c|}{ Comparison: restricted fluids } \\
\hline \multirow[t]{3}{*}{ Outcomes } & \multicolumn{2}{|c|}{ Illustrative comparative risks* $(95 \% \mathrm{Cl})$} & \multirow{3}{*}{$\begin{array}{l}\text { Relative effect } \\
(95 \% \mathrm{CI})\end{array}$} & \multirow{3}{*}{$\begin{array}{l}\text { No of participants } \\
\text { (studies) }\end{array}$} & \multirow{3}{*}{$\begin{array}{l}\text { Quality of the evi- } \\
\text { dence } \\
\text { (GRADE) }\end{array}$} \\
\hline & Assumed risk & Corresponding risk & & & \\
\hline & Restricted flu & Maintenance fluids & & & \\
\hline \multirow[t]{6}{*}{ Death - all participants } & Study popula & & \multirow{6}{*}{$\begin{array}{l}\text { RR } \mathbf{0 . 8 2} \\
\text { (0.53 to } 1.27)\end{array}$} & \multirow{6}{*}{$\begin{array}{l}407 \\
\text { (2 studies) }\end{array}$} & \multirow{6}{*}{$\begin{array}{l}\oplus \oplus \ominus \ominus \\
\text { low1,2 }\end{array}$} \\
\hline & 186 per 1000 & 153 per 1000 & & & \\
\hline & & (99 to 237$)$ & & & \\
\hline & \multicolumn{2}{|c|}{ Moderate risk population } & & & \\
\hline & 213 per 1000 & 175 per 1000 & & & \\
\hline & & (113 to 271$)$ & & & \\
\hline \multirow{6}{*}{$\begin{array}{l}\text { Severe neurological se- } \\
\text { quelae - acute (within } \\
\text { the first } 4 \text { weeks) }\end{array}$} & Study populat & & \multirow{6}{*}{$\begin{array}{l}\text { RR } 0.67 \\
(0.41 \text { to } 1.08)\end{array}$} & \multirow{6}{*}{$\begin{array}{l}407 \\
\text { ( } 2 \text { studies) }\end{array}$} & \multirow{6}{*}{$\begin{array}{l}\oplus \oplus \ominus \ominus \\
\text { low } \mathbf{1 , 2}\end{array}$} \\
\hline & 176 per 1000 & 118 per 1000 & & & \\
\hline & & (72 to 191$)$ & & & \\
\hline & \multicolumn{2}{|c|}{ Moderate risk population } & & & \\
\hline & 252 per 1000 & 169 per 1000 & & & \\
\hline & & (103 to 272$)$ & & & \\
\hline
\end{tabular}




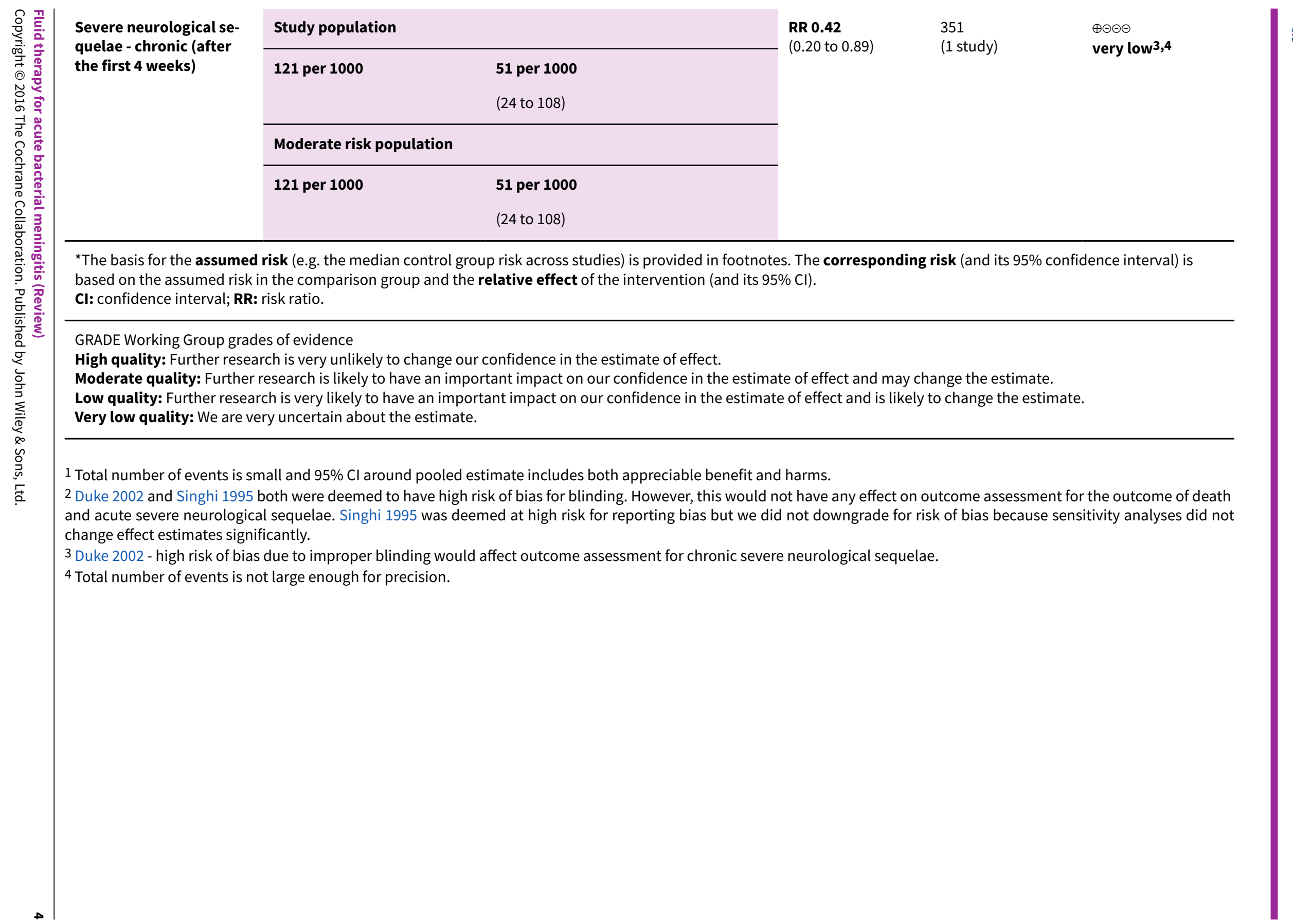




\section{B A C K G R O U N D}

\section{Description of the condition}

Acute bacterial meningitis remains a disease with high mortality and morbidity rates. The outcome in individuals with bacterial meningitis is correlated with many factors, including the age of the person, time and clinical stability before effective antibiotic treatment is begun, type of micro-organism, number of bacteria or quantity of active bacterial products in the cerebrospinal fluid (CSF) at the time of diagnosis, intensity of the host's inflammatory response, and time elapsed to sterilise CSF cultures (Feldman 1977; Mustafa 1990; Saez-Llorens 1990; Waage 1987).

\section{Description of the intervention}

The highest rates of mortality and morbidity occur in the neonatal period and in the elderly. Nearly one in four adults with the illness will die, and many survivors sustain neurological deficits (Bohr 1983; Pfister 1993). Bacterial meningitis causes more than 100,000 deaths worldwide each year in infants and young children (Duke 1998). A 1993 meta-analysis examined the overall and organismspecific frequencies of death and persistent neurological sequelae in children two months to 19 years of age (Baraff 1993). A total of 4920 children with acute bacterial meningitis were included in 45 reports that met the inclusion criteria. Children described in the 19 reports of prospectively-enrolled cohorts from high-income countries had lower mortality than the children included in trials from low-income countries ( $4.8 \%$ versus $8.1 \%$ ) and were more likely to have no sequelae ( $82.5 \%$ versus $73.9 \%)$. A further study that examined the long-term consequences of having meningitis during the first year of life found that $1.8 \%$ of children died within five years (Bedford 2001). Not only did almost a fifth of children with meningitis have a subsequent permanent, severe, or moderately severe disability, but subtle deficits were also more prevalent.

\section{How the intervention might work}

The chances for survival are improved with prompt and adequate antimicrobial and supportive treatment, especially in infants and children, for whom case fatality rates have been reduced to less than $10 \%$ for bacterial meningitis and less than $5 \%$ for meningococcal meningitis (Saez-Llorens 2003). Two Cochrane Reviews examine the effectiveness and safety of steroids and different antibiotic regimens, respectively, which are used in the treatment of acute bacterial meningitis (Brouwer 2015; Prasad 2011).

Careful management of fluid and electrolyte balance is also important in the treatment of meningitis. Over- or under-hydration are associated with adverse outcomes. Fluid restriction in the initial management of meningitis in children has been widely advocated (Conner 1980; Feigin 1992). However, this has also been challenged (Conner 1980; Powell 1990; Singhi 1995). The practice of fluid restriction is based on reports of hyponatraemia (lower than normal concentration of sodium in the extracellular fluid/ blood) that is attributed to increased concentrations of circulating antidiuretic hormone (ADH; a hormone that prevents excretion of water from the body). Over $50 \%$ of children have hyponatraemia at the time of admission (Kaplan 1983). There are associations between the degree of hyponatraemia and the presence of seizures and severity of acute disease, and adverse neurodevelopmental outcomes (Feigin 1977). These findings have subsequently been linked with a high incidence of cerebral oedema (swelling of the brain) in those who die from acute bacterial meningitis (Conner 1980; Dodge 1965; Williams 1964), and it has been suggested that inappropriately increased concentrations of ADH lead to water retention, which in turn exacerbates cerebral swelling. Some researchers have concluded that fluid restriction will avoid exacerbating cerebral oedema and may improve neurological outcome (Brown 1994).

However, clinical dehydration has also been found in children with acute bacterial meningitis without any accompanying significant risk of mortality (Duke 1998). It has also been found that in children who received maintenance fluid plus replacement of volume deficits, the high ADH concentrations normalised over 24 hours; in those who were restricted to two-thirds maintenance fluids, ADH concentrations remained high (Powell 1990). The conclusion from this was that $\mathrm{ADH}$ concentrations are increased in children with meningitis because of hypovolaemia (a decrease in the volume of circulating blood) and only become normal when sufficient sodium and fluid are given.

\section{Why it is important to do this review}

Although it is widely accepted that hyponatraemia is a marker of severe disease in childhood bacterial meningitis, there are different opinions regarding the cause of hyponatraemia at the time of presentation. If dehydration, rather than inappropriately increased antidiuresis, is the major factor in the pathogenesis of hyponatraemia in meningitis, then the rationale for fluid restriction is open to question.

\section{O B JECT IVES}

To evaluate treatment of acute bacterial meningitis with differing volumes of initial fluid administration (up to 72 hours after first presentation) and the effects on death and neurological sequelae.

\section{METHODS}

\section{Criteria for considering studies for this review \\ Types of studies}

Randomised controlled trials (RCTs) examining the effectiveness of different volumes of initial fluid administration in the treatment of acute bacterial meningitis were eligible for inclusion. We planned to consider trials of fluids administered to treat shock at presentation but we found no such trials.

\section{Types of participants}

All age groups with a diagnosis of acute bacterial meningitis, made either by clinical diagnosis or culture of cerebrospinal fluid (CSF) obtained at lumbar puncture, were eligible for inclusion.

\section{Types of interventions}

1. Fluid administered in the initial treatment of acute bacterial meningitis; irrespective of route of administration, type, or volume of fluid.

2. Comparisons of the initial volume of fluid administered in the treatment of acute bacterial meningitis, irrespective of route of administration, or type of fluid, or duration of fluid restriction. 


\section{Types of outcome measures}

\section{Primary outcomes}

1. Death

2. Short-term (within the first four weeks of illness) and longterm (persisting after the first four weeks of illness) neurological sequelae

\section{Secondary outcomes}

1. Oedema (including cerebral)

2. Total body water

3. Extracellular water

4. Serum and urinary sodium

5. Plasma and urinary osmolality

6. Duration of hospital stay

7. Raised intracranial pressure

8. Status epilepticus

\section{Search methods for identification of studies}

\section{Electronic searches}

For this 2016 update we searched:

- the Cochrane Acute Respiratory Infections Group's Specialised Register (21 March 2016);

- the Cochrane Central Register of Controlled Trials (CENTRAL; 2016, Issue 2) in the Cochrane Library using the search strategy in Appendix 1;

- MEDLINE (November 2013 to 21 March 2016; search strategy in Appendix 2);

- CINAHL (November 2013 to 21 March 2016; search strategy in Appendix 3);

- Global Health (November 2013 to 21 March 2016; search strategy in Appendix 4); and

- Web of Science (2013 to 21 March 2016; search strategy in Appendix 5).

For the previous update in 2014 we searched various databases in November 2013 (Appendix 6, Appendix 7, Appendix 8, Appendix 9, Appendix 10). The MEDLINE search was combined with the Cochrane Highly Sensitive Search Strategy for identifying randomised trials in MEDLINE: sensitivity- and precisionmaximising version (2008 revision) (Lefebvre 2011). Details about search strategies for earlier versions of the review are available in Appendix 11 and Appendix 12.

\section{Searching other resources}

We searched references from included trials and contacted trial authors where necessary. In addition, we contacted experts in the field for unpublished works. We searched the following trial registers.

- ClinicalTrials.gov (clinicaltrials.gov; searched March 2016);

- World Health Organization International Clinical Trials Registry Platform (who.int/ictrp/en; searched 6 November 2013).

In much earlier versions the National Health and Medical Research Council (NHMRC) Clinical Trials Register (www.nhmrc.gov.au) and meta-register of controlled trials (www.isrctn.com ) was searched.
We attempted to contact authors of all identified trials, whether open or unpublished. We sought publications in the literature that described, or may have described, the use of fluid therapy for the treatment of acute bacterial meningitis. We applied no language or publication status restrictions. We searched the citation lists of relevant publications, review articles, and abstracts of scientific meetings, and included both published and unpublished studies.

\section{Data collection and analysis}

\section{Selection of studies}

For this 2016 update, two review authors (SB, IM) independently screened all the search results for consideration of inclusion as per eligibility criteria based on title, abstract, and key words initially, and then after accessing full-texts. Any disagreements were to be resolved by consensus, with the Review Group Editor acting as an arbiter. For previous versions of this review, two review authors (HB, IM) undertook study selection after running the search strategies outlined above. Both review authors had independently assessed whether the studies met the inclusion criteria; any discrepancies then were to be resolved by a third author (ROW, see Acknowledgements) but this proved unnecessary.

We sought further information from the trial authors where papers contained insufficient information to make a decision about eligibility. We had to do this for two studies which we excluded based on these communications (Characteristics of excluded studies).

\section{Data extraction and management}

We collected information regarding location of the study, methods of the study (as per quality assessment checklist), participant characteristics (age range, eligibility criteria), types of interventions and outcomes for each included trial. Where possible, we sought missing data from the trial authors. Four review authors had previously (IM, HB, MS , ROW) independently performed data extraction. Any discrepancies were to be resolved by discussion but this proved unnecessary.

\section{Assessment of risk of bias in included studies}

We assessed the risk of bias in the included studies using the criteria described in the Cochrane Handbook for Systematic Reviews of Interventions (Higgins 2011). Two review authors independently extracted information about selection bias (random sequence generation and allocation concealment), detection bias (blinding of outcome assessment), attrition bias (incomplete outcome data), reporting bias (selective reporting), sample size, and exclusions after randomisation, and any other sources of bias .

\section{Measures of treatment effect}

We analysed each dichotomous outcome for effect in terms of a risk ratio (RR) with a $95 \%$ confidence interval $(\mathrm{Cl})$ and combined the outcomes for meta-analysis using Review Manager 5 software (RevMan 2014). Where data were sufficient, we calculated a summary statistic for each outcome using a fixed-effect model. We analysed continuous outcomes as mean differences (MDs) between groups and $95 \% \mathrm{Cls}$. Where data were sufficient, we used a fixedeffect approach in the meta-analysis.

There were two kinds of effect estimates in our study. One, where only a single study contributed to the outcome, in which case 
a fixed-effect model was appropriate, and two, those pooled estimates where there was more than one study (two studies) and little evidence of heterogeneity was detected. Therefore, a fixedeffect model was used.

\section{Unit of analysis issues}

We did not include any studies with non-standard designs. The comparisons under consideration would not lend themselves to cluster-randomised or other similar designs.

\section{Dealing with missing data}

Where there were missing participants due to dropout, we searched for the use of an intention-to-treat (ITT) analysis by the trial authors and reported this in the review. Where there were missing statistics (such as, standard deviations or correlation coefficients) that made analysis impossible, we approached the trial authors. Where there remained missing data, we report this in the review.

\section{Assessment of heterogeneity}

We determined statistical heterogeneity by a combination of visual inspection of graphs of RRs as well as using the $\mathrm{I}^{2}$ statistic (Higgins 2003), and the $\mathrm{Chi}^{2}$ test.

\section{Assessment of reporting biases}

We had intended to investigate for publication bias and other reporting biases initially by the use of funnel plots. However, as there were only three included studies, we were unable to do so.

\section{Data synthesis}

We entered and analysed all data using Review Manager 5 software (RevMan 2014). We discuss methods of analyses for subgroup analysis, investigation of heterogeneity, and sensitivity analyses in the relevant sections.

\section{GRADE and 'Summary of findings' table}

For the 2014 update, two authors (SB, IM) used the GRADE approach to interpret the findings (Schunemann 2011). We used the GRADE profiler software (GRADEpro GDT 2014), and imported data from RevMan 2014 to create Summary of findings for the main comparison containing the following outcomes: death, and acute and chronic severe neurological sequelae. We used the five GRADE considerations (study limitations, consistency of effect, imprecision, indirectness, and publication bias) to assess the quality of a body of evidence as it relates to the studies which contribute data to the meta-analyses for the prespecified outcomes (Atkins 2004). We used methods and recommendations described in Section 8.5 and Chapter 12 of the Cochrane Handbook for Systematic Reviews of Interventions (Higgins 2011). Summary of findings for the main comparison provides information about the overall quality of evidence from trials, the magnitude of effect of the interventions, as well as the sum of the available data for the primary outcomes. We justified all decisions to down- or upgrade the quality of studies using footnotes, and we made comments to aid the reader's understanding of the review where necessary.

\section{Subgroup analysis and investigation of heterogeneity}

We had planned that if there were a sufficient number of trials of adequate size, with the required information recorded in the trial publication, we would conduct subgroup analyses by:
- age;

- volume of fluid administered;

- organism causing the meningitis;

- hypoperfusion status at enrolment; and

- clinical diagnosis versus laboratory-confirmed diagnosis.

We assessed clinical heterogeneity by establishing the overall mortality rates and duration of symptoms, where possible. We used this to distinguish between participants studied in different health settings. We did not deem meta-analysis appropriate where it was evident that studies were undertaken in different health contexts.

\section{Sensitivity analysis}

We had planned to perform an a priori sensitivity analysis on results to look at the possible contribution of differences in methodological quality, but we were unable to do this due to the paucity of trials.

\section{RE S U L T S}

\section{Description of studies}

\section{Results of the search}

For this 2016 update we identified 824 records (CENTRAL $=128$, $\mathrm{CINAHL}=29$, Global Health $=298, \mathrm{MEDLINE}=221$, Web of Science $=$ 133, ClinicalTrials.gov $=14$, reference searching $=1$ ). After removing duplicates $(n=139)$, we screened 685 records. We recovered fulltexts for three of them (Pelkonen 2011; Roine 2014; van Paridon 2015), but we did not find any to be eligible for inclusion. Reasons for exclusion are documented in the Characteristics of excluded studies table.

For the 2014 update, with duplicates removed (including duplicates of the records sent in 2010) there were 496 search results. We removed animal studies $(n=49)$ and screened 447 search results (Maconochie 2014). We excluded 445 search results on the basis of title or abstract and two on the basis of full-text inspection. We did not find any studies in the grey literature. Reasons for exclusion are given in the Characteristics of excluded studies table.

In the 2011 update, six abstracts identified in the search initially appeared to fit the inclusion criteria for the review (Maconochie 2011). After obtaining the full papers, we excluded three of these, leaving three trials eligible for inclusion (420 children). In the 2008 update, we retrieved 105 records from the search of the electronic databases but did not find any new included trials for inclusion (Maconochie 2008).

\section{Included studies}

\section{Trial design characteristics}

\section{Volume and constitution of fluid}

The Duke 2002 trial compared milk-based fluids delivered at 60\% of that required for maintenance fluids with $100 \%$ of normal maintenance fluids. Maintenance fluids were defined as "100 ml/ $\mathrm{kg} /$ day for the first $10 \mathrm{~kg}$ of body weight, $50 \mathrm{ml} / \mathrm{kg}$ for the second 10 $\mathrm{kg}$, and $20 \mathrm{ml} / \mathrm{kg}$ for over $20 \mathrm{~kg} "$. The milk-based fluids comprised expressed breast milk or other milk feed given via a nasogastric tube for at least 48 hours, or longer with reduced conscious state, convulsions, impaired upper airway reflexes, or persistent respiratory distress. Normal maintenance fluids (defined as above) 
of a solution containing $0.45 \%$ sodium chloride and $5 \%$ dextrose plus $10 \mathrm{mmol} / \mathrm{L}$ of potassium chloride per litre were delivered intravenously for at least the first 48 hours.

The Powell 1990 trial compared two-thirds of required maintenance fluids (similarly defined as "100 ml/kg for the first $10 \mathrm{~kg}$ of body weight, plus $50 \mathrm{ml} / \mathrm{kg}$ for the next $10 \mathrm{~kg}$ (10 kg to $20 \mathrm{~kg}$ ), plus $20 \mathrm{ml} / \mathrm{kg}$ for each kilogram in excess of $20 \mathrm{~kg} "$ ) with full maintenance fluids, plus replacement fluids for any estimated deficit over 24 hours. Rehydration was begun by administering 10 $\mathrm{ml} / \mathrm{kg}$ or $15 \mathrm{ml} / \mathrm{kg}$ by rapid intravenous infusion. Fluids were given intravenously with the composition determined by the attending consultant.

The Singhi 1995 trial compared restricted fluids at $65 \%$ of the calculated maintenance fluid requirement with maintenance fluid requirements $(110 \mathrm{ml} / \mathrm{kg}$ for first $10 \mathrm{~kg}, 50 \mathrm{ml} / \mathrm{kg}$ for next $10 \mathrm{~kg}$ and $25 \mathrm{ml} / \mathrm{kg}$ for subsequent weight), both given intravenously. The restricted fluids comprised one-fifth normal saline in $5 \%$ dextrose for 24 hours, followed by "a gradual liberalisation at a rate of 10 $\mathrm{ml} / \mathrm{kg}$ over eight hours, if, after 24 hours of hospital stay, the serum sodium and plasma osmolality had returned to normal and there were no clinical signs of dehydration".

\section{Duration of fluid therapy}

The Duke 2002 study administered fluids for 48 hours; the Powell 1990 study administered fluids for 24 hours; and the Singhi 1995 study administered fluids for 24 hours, with a gradual increase thereafter until children in both arms received the full normal maintenance requirement after 48 hours.

\section{Baseline characteristics of participants}

\section{Age}

All studies included only children. Duke 2002 included children between one month and 12 years of age, Powell 1990 included children between three months and 16 years, and Singhi 1995 included children between two months and seven years of age.

\section{Health status}

The children in the study carried out in Papua New Guinea were from a population in which $25 \%$ were undernourished at the time of their presentation (Duke 2002). In regard to the meningitis symptoms, the mean duration of symptoms was six days, with twothirds of children having convulsions, before presentation; $20 \%$ of the children were hypoglycaemic.

The Powell 1990 study gave no specific details, but said that they only enrolled "previously healthy children". Malnourished children were excluded from the Singhi 1995 study, and children had a duration of symptoms ranging from one to 10 days on presentation.

\section{Diagnostic techniques used to establish a diagnosis of bacterial meningitis}

The Duke 2002 study made a diagnosis according to clinical signs of meningitis and a cloudy or turbid cerebrospinal fluid (CSF) with a moderate or large number of leucocytes and amount of protein, determined by dipstick testing (Multistix 10 SG). The Powell 1990 study diagnosed meningitis on the basis of clinical examination, CSF cytology, and chemical studies. The Singhi 1995 study made a diagnosis on a suggestive history, physical examination, CSF findings of hypoglycorrhachia, increased protein concentration, and polymorphonuclear leucocytosis.

\section{Studied outcomes}

Death

Two studies reported death as an outcome (Duke 2002; Singhi 1995). Personal communication with the lead author of the Powell 1990 study reported no fatalities.

Short-term (within the first four weeks of illness) and long-term (persisting after the first four weeks of illness) neurological sequelae

Two studies reported acute neurological sequelae (Duke 2002; Singhi 1995). One of these studies also reported individual neurological components at 14 days (spasticity, hemiparesis/ hemiplegia, visual impairment, and no response to sound) and neurological sequelae at three months (Duke 2002).

\section{Seizures}

Duke 2002 reported the incidence of seizures at both 72 hours and 14 days. In the 2014 update of this review, 'seizures' was not treated as a separate secondary outcome since this outcome is already captured within the primary outcome 'acute (short-term) neurological sequelae'.

\section{Oedema (including cerebral)}

One study reported facial oedema, pulmonary oedema, and hydrocephalus (Duke 2002).

\section{Total body water}

One study reported total body water as an outcome (Singhi 1995).

\section{Extracellular water}

One study reported extracellular water as an outcome (Singhi 1995).

\section{Serum and urinary sodium}

Two studies reported comparisons of mean serum-sodium concentrations (Powell 1990; Singhi 1995). Duke 2002 reported the proportion of children with serum-sodium concentrations below $130 \mathrm{mmol} /$ litre at 72 hours. One study reported urinary sodium as an outcome (Singhi 1995).

\section{Plasma and urinary osmolality}

One study reported plasma and urinary osmolality as an outcome (Singhi 1995).

\section{Duration of hospital stay}

No study reported duration of hospital stay as an outcome.

\section{Raised intracranial pressure}

No study reported on raised intracranial pressure.

\section{Status epilepticus}

No study reported on incidence of status epilepticus.

\section{Excluded studies}

We excluded three studies as they were not RCTs (Brown 1994; Duke 1998; Floret 1999), one study because the interventions and comparators were not relevant (Berkley 2004), and another study 
because insufficient data on culture-positive bacterial meningitis were available (Maitland 2013).

\section{Risk of bias in included studies}

A graphical representation of the risk of bias for the included studies is shown in Figure 1. A summary of methodological quality of the included trials is given in Figure 2.

Figure 1. Risk of bias graph: review authors' judgements about each risk of bias item presented as percentages across all included studies.

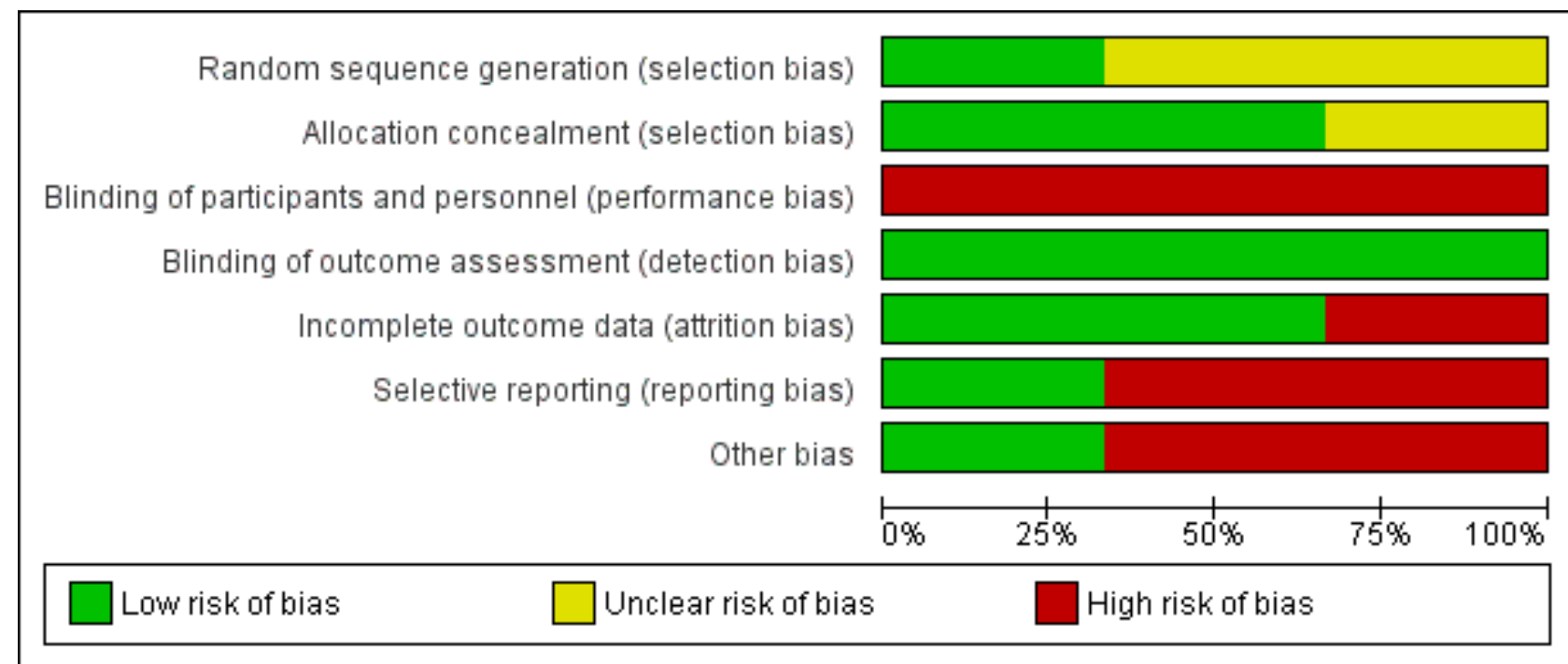


Figure 2. Risk of bias summary: review authors' judgements about each risk of bias item for each included study.

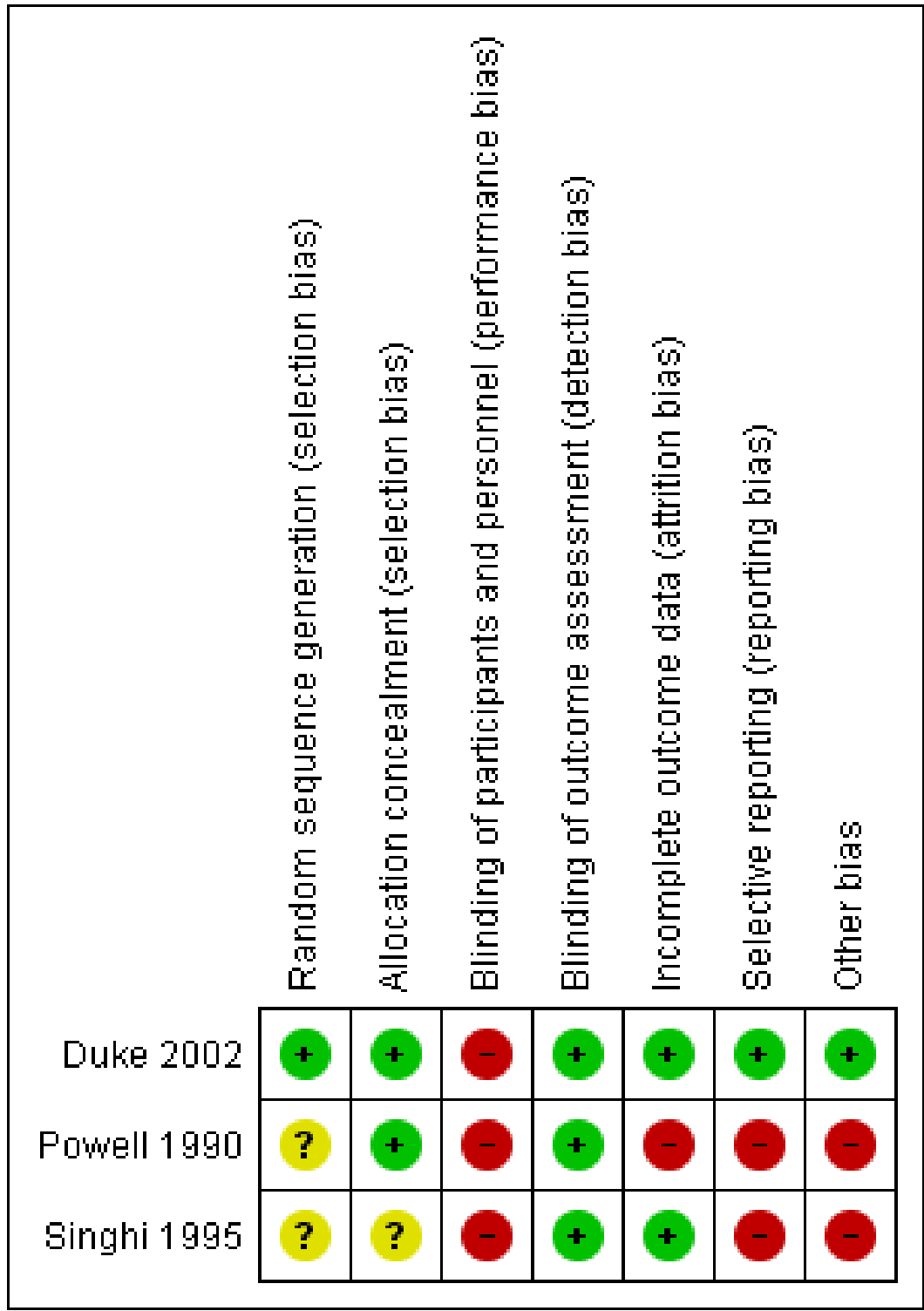

\section{Allocation}

Two studies used opaque, sealed, sequentially-numbered envelopes (Duke 2002; Powell 1990). The remaining study used a random numbers table (Singhi 1995) and judged to have low risk. Two trials displayed adequate allocation concealment (Duke 2002; Powell 1990). The quality of allocation concealment in the third study was unclear (Singhi 1995).

\section{Blinding}

\section{Performance bias}

Blinding of participants and personnel was high risk for all trials

\section{Detection bias}

This was judged to be low risk for all the three trials for the outcomes of death and acute severe neurological sequelae as clinically they are quite objective and obvious even though no blinding was done.Since no blinding was done for outcome assessment it would be high risk for the outcome of chronic sever neurological sequale where the clinical manifestation would not be so obvious.

\section{Attrition bias}

The attrition bias was found to be low risk for two trials (Duke 2002; Singhi 1995) and high risk for one (Powell 1990).

\section{Reporting bias}

Reporting bias was found to be high risk in two studies (Powell 1990; Singhi 1995) and low risk in one study (Duke 2002).

\section{Power calculations}

Two studies documented power calculations (Duke 2002; Singhi 1995). Duke 2002 calculated a required participation of 354 to detect a one-third reduction in adverse outcomes. The study randomised 357 children and analysed results for 346 children immediately at completion of treatment. Singhi 1995 calculated 
that 31 children in each group were needed to detect a $25 \%$ change in intact survival rate from $50 \%$, with a significance of 0.05 . This study was terminated early, but enrolled 25 in each group.

\section{Number of centres}

Duke 2002 had three participating centres. The remaining two were single-centre studies (Powell 1990; Singhi 1995).

\section{Intention-to-treat (ITT) analysis}

No study reported an ITT analysis.

\section{Incomplete outcome data}

The largest study had relatively small numbers of dropouts (11 of 357 enrolled children) by the end of treatment, when most of the outcomes were measured (Duke 2002). By three months from diagnosis there were over $10 \%$ dropouts.

The Powell 1990 study had five exclusions from 24 children enrolled, and this would have introduced the possibility of significant bias. Singhi 1995 had no dropouts.

\section{Selective reporting}

There was no evidence of selective reporting of data in Duke 2002; both short-term and longer-term morbidities were reported. Powell 1990 only reported short-term sodium levels. Singhi 1995 only reported total numbers with short-term neurological impairment and did not attempt to break these down by type of impairment.

\section{Other potential sources of bias}

The main concern was the marked discrepancy in size between the largest study and the two other very small RCTs. The Singhi 1995 trial was stopped prematurely owing to observance of "a trend toward poor outcome in the restricted-fluid group", and this is also a potential source of bias.

\section{Effects of interventions}

See: Summary of findings for the main comparison Maintenance fluids versus restricted fluids for acute bacterial meningitis

\section{Primary outcomes}

\section{Death}

\section{All participants, regardless of serum sodium at enrolment}

The meta-analysis of the three studies (420 children) for deaths (Duke 2002; Powell 1990; Singhi 1995), where one study reported no fatality amongst their participants (Powell 1990), found no significant difference between deaths in the maintenance-fluid and restricted-fluid groups; risk ratio (RR) $0.82,95 \%$ confidence interval (CI) 0.53 to 1.27 ; low quality evidence (Summary of findings for the main comparison; Analysis 1.1.1).

\section{Participants with or without hyponatraemia}

The Singhi 1995 study that subdivided maintenance-fluid and restricted-fluid groups into children with or without hyponatraemia at presentation found no significant difference in death rates in either those presenting with hyponatraemia ( 26 children) or those without hyponatraemia ( 24 children). With hyponatraemia, the RR for children given the two different fluid intakes was RR $0.15,95 \%$ $\mathrm{Cl} 0.01$ to 2.50 (Analysis 1.1.2); without hyponatraemia, the RR was $0.79,95 \% \mathrm{Cl} 0.16$ to 3.90 (Analysis 1.1.3).

\section{Short-term (within the first four weeks of illness) and long- term (persisting after the first four weeks of illness) neurological sequelae}

\section{Short-term neurological sequelae}

The meta-analysis of acute severe neurological sequelae (2 studies, 407 children) found no significant difference between the maintenance-fluids and restricted-fluids groups (RR $0.67,95 \% \mathrm{Cl}$ 0.41 to 1.08 ; low quality evidence) (Summary of findings for the main comparison; Analysis 1.2.1).

Data on mild to moderate sequelae at 14 days ( 1 study, 357 children) also showed no significant difference between maintenance-fluid and restricted-fluid groups (RR 1.24, 95\% $\mathrm{Cl} 0.58$ to 2.65) (Analysis 1.3.1).

However, when neurological sequelae were categorised further, the available data produced the following results.

- Hemiparesis/hemiplegia (1 study, 357 children): no significant difference between groups (RR $0.97,95 \% \mathrm{Cl} 0.52$ to 1.81) (Analysis 1.4.1).

- Spasticity (1 study, 357 children): there was a statistically significant difference in favour of the maintenance-fluid group (RR 0.50, 95\% Cl 0.27 to 0.93) (Analysis 1.5.1).

- Seizures (1 study, 357 children): there was a statistically significant difference in seizure activity at both 72 hours (RR 0.59 , $95 \% \mathrm{Cl} 0.42$ to 0.83 ) and 14 days (RR $0.19,95 \% \mathrm{Cl} 0.04$ to 0.88 ) in favour of the maintenance-fluid group (Analysis 1.6).

- Visual impairment and response to sound (1 study, 357 children): there was no statistically significant difference in either group. On visual impairment the RR was $0.77,95 \% \mathrm{Cl} 0.44$ to 1.35 (Analysis 1.7) and on response to sound, RR $0.60,95 \% \mathrm{Cl} 0.25$ to 1.41 (Analysis 1.8).

\section{Participants with or without hyponatraemia}

Analyses of data from participants with and without hyponatraemia at presentation showed no significant difference in acute neurological sequelae for either subgroup. Without hyponatraemia, the RR for children given maintenance fluids or restricted fluids was $\mathrm{RR} 0.59,95 \% \mathrm{Cl} 0.13$ to 2.64 (Analysis 1.2.3); with hyponatraemia, RR $0.91,95 \% \mathrm{Cl} 0.34$ to 2.47 (Analysis 1.2.4).

\section{Long-term neurological sequelae}

The data relating to chronic severe neurological sequelae (1 study, 351 children) showed a statistically significant difference at threemonth follow-up in favour of those in the maintenance-fluid groups: RR $0.42,95 \% \mathrm{Cl} 0.20$ to 0.89 ; very low quality evidence (Summary of findings for the main comparison; Analysis 1.2.2).

\section{Secondary outcomes}

\section{Oedema (including cerebral)}

The data on facial oedema ( 1 study, 357 children) showed a statistically significant difference in favour of the restricted-fluids group: RR $5.47,95 \% \mathrm{Cl} 2.65$ to 11.27 . There was no statistically significant difference in either pulmonary oedema (RR $8.75,95 \%$ $\mathrm{Cl} 0.47$ to 161.38 ) or hydrocephalus (RR $0.28,95 \% \mathrm{Cl} 0.06$ to 1.32 ) (Analysis 1.9). 


\section{Total body water}

The data on change in total body water at 48 hours after admission ( 1 study; 24 children without hyponatraemia, 26 children with hyponatraemia) showed a statistically significantly greater reduction in the restricted-fluids group in both non-hyponatraemic and hyponatraemic children: mean difference (MD) (meq/litre) 24.50, 95\% Cl 9.91 to 39.09; and MD (meq/litre) 36.00, 95\% Cl 19.83 to 52.17 , respectively (Analysis 1.10).

\section{Extracellular water}

The data on reduction in extracellular water at 48 hours after admission ( 1 study; 24 children without hyponatraemia, 26 children with hyponatraemia) showed a greater reduction in the restrictedfluid groups: non-significant for non-hyponatraemic children: MD (meq/litre) $22.90,95 \% \mathrm{Cl}-1.11$ to 46.91 ; and a statistically significant change in hyponatraemic children: MD (meq/litre) $35.00,95 \% \mathrm{Cl}$ 16.86 to 53.14 (Analysis 1.11).

\section{Serum and urinary sodium}

Duke 2002 reported the proportion of children with serum sodium concentrations below $130 \mathrm{mmol} /$ litre at 72 hours and found no statistically significant difference between the restricted-fluid and maintenance-fluid groups: RR $0.72,95 \% \mathrm{Cl} 0.34$ to 1.55 (Analysis not shown).

We did not attempt a meta-analysis of the two studies comparing mean sodium concentrations, as Powell 1990 measured serum sodium at 24 hours and Singhi 1995, at 48 hours. The Powell 1990 study (13 children with bacterial meningitis) reported all children together and found no statistically significant difference in mean serum sodium at 24 hours: MD (meq/litre) $3.00,95 \% \mathrm{Cl}$ -0.94 to 6.94 . The Singhi 1995 study (1 study; 24 children without hyponatraemia, 26 children with hyponatraemia) subgrouped children by hyponatraemia status at study entry. The study found a statistically significant difference in favour of the restricted-fluid group in children with hyponatraemia (MD (meq/litre) $-4.20,95 \%$ $\mathrm{Cl}-6.20$ to -2.2$)$. In the original paper, the statistical difference in favour of restricted fluids in children without hyponatraemia (MD (meq/litre) $-3.50,95 \% \mathrm{Cl}-7.58$ to $0.58, \mathrm{P}=0.09$ ) was reported as statistically significant, but this is not the case, as evident from examination of the effect estimate and the $95 \% \mathrm{Cl}$. This study also found a significant difference in the change in serum sodium from baseline, in favour of the restricted-fluid group, in children both with and without hyponatraemia. Without hyponatraemia, the MD (meq/litre) was $-5.8,95 \% \mathrm{Cl}-11.59$ to -0.01 ; with hyponatraemia, MD (meq/litre) $-4.40,95 \% \mathrm{Cl}-6.97$ to -1.83 (Analysis 1.12).

The one study ( 24 children without hyponatraemia at admission, 26 children with hyponatraemia) that reported urinary sodium found no significant difference at 48 hours in mean urinary sodium in children without hyponatraemia (MD (meq/litre) $-14.0,95 \% \mathrm{Cl}$ -31.60 to 3.6) but a statistically significant difference in children with hyponatraemia at admission (MD (meq/litre) $-21.00,95 \% \mathrm{Cl}-34.14$ to -7.86). There was no significant change from baseline at 48 hours either in children without hyponatraemia (MD (meq/litre) 1.00, 95\% $\mathrm{Cl}-12.22$ to 14.22 ) or with hyponatraemia (MD (meq/litre) $0.0,95 \%$ $\mathrm{Cl}-8.94$ to 8.94 ) (Analysis 1.13).

\section{Plasma and urinary osmolality}

There was a statistically significant difference in the change in plasma osmolality after 48 hours, with a greater increase in the restricted-fluid group, in both the children presenting without hyponatraemia (1 study, 24 children): MD (meq/litre) $-5.00,95 \% \mathrm{Cl}$ -9.82 to -0.18 ; and children presenting with hyponatraemia ( 1 study, 26 children): MD (meq/litre) $-6.00,95 \% \mathrm{Cl}-11.36$ to -0.64 (Analysis 1.14).

\section{Duration of hospital stay}

No study reported on duration of hospital stay.

\section{Raised intracranial pressure}

No study reported on raised intracranial pressure.

\section{Status Epilepticus}

No study reported on incidence of status epilepticus.

\section{IS C U S S I O N}

\section{Summary of main results}

The small number of studies identified by this review did not show any statistically significant difference in mortality or acute severe neurological sequelae from restricting fluids. Two studies reported high mortality rates overall, well above 10\% (Duke 2002; Singhi 1995; 407 children). The third study included very small numbers (19 children analysed), and reported no deaths (Powell 1990). Meta-analysis of the two studies reporting neurological sequelae demonstrated statistically significant reductions in the rates of early spasticity and seizures, and later overall neurological sequelae, in children receiving maintenance fluids. There were no statistically significant differences in overall shortterm neurological sequelae or in risk of hemiparesis, visual, or hearing impairment.

Two of the studies involved very small numbers of children from single centres (Powell 1990; Singhi 1995). The mortality and morbidity results, therefore, are dominated by the Duke 2002 study. The long delays before presentation and a high rate of malnutrition in the children in this study may have been associated with a high rate of dehydration at presentation. The finding of a higher rate of neurological sequelae in the restricted-fluid group in this study could result from inadequate initial treatment of dehydration. This might not be relevant in settings where patients present earlier.

\section{Overall completeness and applicability of evidence}

The three included studies were insufficient to evaluate the review objective of evaluating different volumes of initial fluid administrations on treatment outcomes of acute bacterial meningitis. We did not find any trial answering the review question for adult patients. All the trials were conducted in in-hospital settings and no trials were carried out in primary care or outof-hospital settings, where initial fluid therapy is often instituted, and the patients referred to a tertiary care set-up for specialised care. Trials done in out-of-hospital and primary healthcare settings might be more relevant to low- and middle-income nations, where healthcare delivery is not well monitored, and generally unstructured (Maher 2011).

The largest of the three studies included multiple outcomes relevant to the review question (Duke 2002). Its shortcoming was that it could only address the question in settings with high mortality and morbidity rates and long delays before presentation. 
The other two included studies were too small to allow any conclusions to be drawn. None of the studies included adults.

The results of short-term fluid and electrolyte balance do not in themselves provide adequate evidence on which to change practice. The reporting of sodium levels was inconsistent so that it was not possible to undertake a meta-analysis.

The quality of evidence for the primary and secondary outcomes was low to very low and thus insufficient to guide clinical practice.

\section{Quality of the evidence}

We assessed the overall quality of the evidence using the GRADE approach (Schunemann 2011), as shown in Summary of findings for the main comparison. The overall quality of the evidence for maintenance-fluid versus restricted-fluid regimens for children with acute bacterial meningitis was low for the outcomes of death, and acute severe neurological sequelae, and very low for chronic severe neurological sequelae. In this 2016 update we revised the GRADE table to reflect current Cochrane standards, and improve clarity and consistency of reporting results.

\section{Potential biases in the review process}

We searched a number of electronic databases using a number of search terms. We expect that our search strategy has been successful in identifying all relevant studies. Standard Cochrane methodologies have been used to minimise any bias in the review process.

\section{Agreements and disagreements with other studies or reviews}

There are no systematic reviews which have explored this research question.

\section{AUTHORS' CONCLUSIONS}

\section{Implications for practice}

There is a lack of high quality evidence to guide the use of fluid therapy for acute bacterial meningitis. There are no trials in adult or elderly populations; all trials were in children. The metaanalysis found no significant difference between the maintenancefluid and restricted-fluid groups in number of deaths (low quality of evidence), or acute severe neurological sequelae (low quality of evidence). Some evidence was found favouring maintenance fluid over restrictive regimens for the outcome of chronic severe neurological sequelae events at three months follow-up, although the quality of evidence is very low and hence not enough to guide practice. Most of the evidence was from high mortality setting.

\section{Implications for research}

Future randomised clinical trials should evaluate maintenance fluid versus restricted fluid for acute bacterial meningitis. Trials in adult populations, particularly elderly populations, are needed and in countries with high and low mortality rates for acute bacterial meningitis. Large, high quality trials are also needed to assess the effectiveness of either restricting or administering maintenance fluids in populations where people present early and where mortality rates are low. Trials also need to focus on important outcomes such as duration of hospital stay and raised intracranial pressure.

\section{ACKNOWLEDGEMENTS}

The review authors would like to acknowledge the major contribution of the late Richmal Oates-Whitehead. She was the person who turned the idea of this review into a reality by doing much of the work for the first published version (Oates-Whitehead 2005). Richmal died suddenly and was not therefore able to contribute to this version. She jointly (with IM) conceptualised the review, took the lead in writing the protocol and overall review, performed initial searches of databases for trials, was involved in selecting trials for inclusion, and performed independent data extraction and quality assessment of the included trials. The late Richmal is not included as an author on this update although she was the original contact reviewer in the first published version in 2005. Richmal died after the publication of that version.

Morwenna Stewart (MS) was an author on the original review and the 2008 update. Morwenna performed independent data extraction and quality assessment of the included trials, and commented on all drafts of the review.

Harry Baumer (HB) commented on drafts of the protocol and was involved in selecting trials for inclusion in the review; performed independent data extraction and quality assessment of the included trials; and commented on all drafts of the review. HB led the previous update.

The review authors would like to thank Dr Keith Powell and Dr Sunit Singhi for taking time to reply to requests for further information on their respective studies; Liz Dooley, Managing Editor of the Cochrane Acute Respiratory Infections (ARI) Group, Carol Wical, Ruth Foxlee and Sarah Thorning, former members of the ARI Group editorial team, for their help and support. Finally, we would like to thank the following people for commenting on drafts of this review: Hayley Edmonds, Robert Heyderman, Sree Nair, George Swingler and Diederik van de Beek. 


\section{R E F E R E N C E S}

\section{References to studies included in this review}

Duke 2002 \{published data only\}

Duke T, Mokela D, Frank D, Michael A, Paulo T, Mgone J, et al. Management of meningitis in children with oral fluid restriction or intravenous fluid at maintenance volumes: a randomised trial. Annals of Tropical Paediatrics 2002;22(2):145-57.

Powell 1990 \{published data only\}

Powell K, Sugarman L, Eskenazi A, Woodin K, Kays M, McCormick K, et al. Normalization of plasma arginine vasopressin concentrations when children with meningitis are given maintenance plus replacement fluid therapy. Journal of Pediatrics 1990;117(4):515-22.

\section{Singhi 1995 \{published data only\}}

Singhi S, Singhi P, Srinivas B, Narakesri H, Ganguli N, Sialy R, et al. Fluid restriction does not improve the outcome of acute meningitis. Pediatric Infectious Diseases Journal 1995;14(6):495-503.

\section{References to studies excluded from this review}

Berkley 2004 \{published data only\}

Berkley JA, Versteeg AC, Mwangi I, Lowe BS, Newton CR. Indicators of acute bacterial meningitis in children at a rural Kenyan district hospital. Pediatrics 2004;114(6):e713-9.

\section{Brown 1994 \{published data only\}}

Brown L, Feigin R. Bacterial meningitis: fluid balance and therapy. Pediatrics Annals 1994;23(2):93-8.

Duke 1998 \{published data only\}

Duke T. Fluid management of bacterial meningitis in developing countries. Archives of Diseases in Childhood 1998;79(2):181-5.

Floret 1999 \{published data only\}

Floret D. Hydration and meningitis. Archives de Pediatrie 1999;6(2):199-202.

Maitland 2013 \{published and unpublished data\}

Maitland K, George EC, Evans JA, Kiguli S, Olupot-Olupot P, Akech SO, et al. Exploring mechanisms of excess mortality with early fluid resuscitation: insights from the FEAST trial. BMC Medicine 2013;11:68. [DOI: 10.1186/1741-7015-11-68]

\section{Pelkonen 2011 \{published data only\}}

Pelkonen T, Roine I, Cruzeiro ML, Pitkäranta A, Kataja M, Peltola H. Slow initial $\beta$-lactam infusion and oral paracetamol to treat childhood bacterial meningitis: a randomised, controlled trial. Lancet Infectious Disease 2011;11(8):613-21.

\section{Roine 2014 \{published data only\}}

Roine I, Pelkonen T, Bernardino L, Leite M, Kataja M, Pitkaranta A, et al. Factors affecting time to death from start of treatment among children succumbing to bacterial meningitis. Pediatric Infectious Disease Journal 2014;33(8):789-92. van Paridon 2015 \{published data only\}

van Paridon BM, Sheppard C, Garcia GG, Joffe AR, Alberta Sepsis N. Timing of antibiotics, volume, and vasoactive infusions in children with sepsis admitted to intensive care. Critical Care 2015;19:293. [DOI: 10.1186/s13054-015-1010-x]

\section{Additional references}

\section{Atkins 2004}

Atkins D, Best D, Briss PA, Eccles M, Falck-Ytter Y, Flottorp S, et al. GRADE Working Group. Grading quality of evidence and strength of recommendations. BMJ 2004;328(7454):1490.

\section{Baraff 1993}

Baraff L, Lee S, Schriger D. Outcomes of bacterial meningitis in children: a meta-analysis. Pediatric Infectious Diseases Journal 1993;12(5):389-94

\section{Bedford 2001}

Bedford H, De Louvois J, Halket S, Peckham C, Hurley R, Harvey D. Meningitis in infancy in England and Wales: follow up at age 5 years. BMJ 2001;323(7312):533-6.

\section{Bohr 1983}

Bohr V, Hansen B, Kjersem H, Rasmussen N, Johnsen N, Kristensen HS, et al. Sequelae from bacterial meningitis and their relation to the clinical condition during acute illness, based on 667 questionnaire returns. Part II of a three part series. Journal of Infection 1983;7(2):102-10.

\section{Brouwer 2015}

Brouwer MC, McIntyre P, Prasad K, van de Beek D. Corticosteroids for acute bacterial meningitis. Cochrane Database of Systematic Reviews 2015, Issue 9. [DOI: 10.1002/14651858.CD004405.pub5]

\section{Conner 1980}

Conner W, Minielly J. Cerebral oedema in fatal meningococcaemia. Lancet 1980;2(8201):967-9.

\section{Dodge 1965}

Dodge P, Swartz M. Bacterial meningitis: a review of selected aspects, II. Special neurologic problems, postmeningitic complications and clinicopathological correlations. New England Journal of Medicine 1965;272:1003-10.

\section{Feigin 1977}

Feigin R, Kaplan S. Inappropriate secretion of antidiuretic hormone in children with bacterial meningitis. American Journal of Clinical Nutrition 1977;30(9):1482-4.

\section{Feigin 1992}

Feigin R, McCracken G, Klein J. Diagnosis and management of meningitis. Pediatric Infectious Diseases Journal 1992;11(9):785-814. 


\section{Feldman 1977}

Feldman W. Relation of concentrations of bacteria and bacterial antigen in cerebrospinal fluid to prognosis in patients with bacterial meningitis. New England Journal of Medicine 1977;296(8):433-5.

\section{GRADEpro GDT 2014 [Computer program]}

GRADE Working Group, McMaster University. GRADEpro GDT. Version accessed before 16 September 2016. Hamilton (ON): GRADE Working Group, McMaster University, 2014.

\section{Higgins 2003}

Higgins JPT, Thompson SG, Deeks JJ, Altman DG. Measuring inconsistency in meta-analyses. BMJ 2003;327(7414):557-60.

\section{Higgins 2011}

Higgins JP, Green S, editor(s). Cochrane Handbookfor Systematic Reviews of Interventions Version 5.1.0 (updated March 2011). The Cochrane Collaboration, 2011. Available from handbook.cochrane.org.

\section{Kaplan 1983}

Kaplan S, Feigin R. Treatment of meningitis in children. Pediatric Clinics of North America 1983;30(2):259-69.

\section{Lefebvre 2011}

Lefebvre C, Manheimer E, Glanville J. Chapter 6: Searching for studies. In: Higgins JP, Green S, editor(s). Cochrane Handbook for Systematic Reviews of Interventions Version 5.1.0 (updated March 2011). The Cochrane Collaboration, 2011. Avaiable from handbook.cochrane.org.

\section{Maher 2011}

Maher D, Ford N. Action on noncommunicable diseases: balancing priorities for prevention and care. Bulletin of the World Health Organization 2011;89(8):547-547A. [DOI: 10.2471/ BLT.11.091967.]

\section{Mustafa 1990}

Mustafa M, Ramilo O, Saez-Llorens X, Olsen K, Magness R, McCracken G. Cerebrospinal fluid prostaglandins, interleukin 1 beta, and tumor necrosis factor in bacterial meningitis. Clinical and laboratory correlations in placebo-treated and dexamethasone-treated patients. American Journal of Diseases of Children 1990;144(8):883-7.

\section{Pfister 1993}

Pfister H, Feiden W, Einhaupl K. Spectrum of complications during bacterial meningitis in adults. Results of a prospective clinical study. Archives of Neurology 1993;50(6):575-81.

\section{Prasad 2011}

Prasad K, Kumar A, Singhal T, Gupta PK. Third generation cephalosporins versus conventional antibiotics for treating acute bacterial meningitis. Cochrane Database of Systematic Reviews 2011, Issue 10. [DOI: 10.1002/14651858.CD001832.pub3]

\section{RevMan 2014 [Computer program]}

Nordic Cochrane Centre, The Cochrane Collaboration. Review Manager 5 (RevMan 5). Version 5.3. Copenhagen: Nordic Cochrane Centre, The Cochrane Collaboration, 2014.

\section{Saez-Llorens 1990}

Saez-Llorens X, McCracken G. Bacterial meningitis in neonates and children. Infectious Disease Clinics in North America 1990;4(4):623-44

\section{Saez-Llorens 2003}

Saez-Llorens X, McCracken G. Bacterial meningitis in children. Lancet 2003;361(9375):2139-48.

\section{Schunemann 2011}

Schünemann HJ, Oxman AD, Vist GE, Higgins JP, Deeks JJ, Glasziou P, et al. Chapter 12: Interpreting results and drawing conclusions. In: Cochrane Handbook for Systematic Review of Interventions Version 5.1.0 (updated March 2011). The Cochrane Collaboration, 2011. Available from handbook.cochrane.org.

\section{Waage 1987}

Waage A, Halstensen A, Espevik T. Association between tumour necrosis factor in serum and fatal outcome in patients with meningococcal disease. Lancet 1987;1(8529):335-7.

\section{Williams 1964}

Williams C, Swanson A, Chapman J. Brain swelling with acute purulent meningitis. Report of treatment with hypertonic intravenous urea. Pediatrics 1964;34:220-7.

\section{References to other published versions of this review}

Maconochie 2008

Maconochie I, Baumer H, Stewart MER. Fluid therapy for acute bacterial meningitis. Cochrane Database of Systematic Reviews 2008, Issue 1. [DOI: 10.1002/14651858.CD004786.pub3]

\section{Maconochie 2011}

Maconochie IK, Baumer H. Fluid therapy for acute bacterial meningitis. Cochrane Database of Systematic Reviews 2011, Issue 2. [DOI: 10.1002/14651858.CD004786.pub3]

\section{Maconochie 2014}

Maconochie IK, Bhaumik S. Fluid therapy for acute bacterial meningitis. Cochrane Database of Systematic Reviews 2014, Issue 5. [DOI: 10.1002/14651858.CD004786.pub4]

\section{Oates-Whitehead 2004}

Oates-Whitehead RM, Maconochie I, Baumer JH, Stewart M. Fluid therapy for acute bacterial meningitis. Cochrane Database of Systematic Reviews 2004, Issue 2. [DOI: 10.1002/14651858.CD004786]

\section{Oates-Whitehead 2005}

Oates-Whitehead RM, Maconochie I, Baumer H, Stewart MER. Fluid therapy for acute bacterial meningitis. Cochrane Database of Systematic Reviews 2005, Issue 3. [DOI: 10.1002/14651858.CD004786.pub2] 
CHARACTERISTICS OF STUDIES

Characteristics of included studies [ordered by study ID]

Duke 2002

\begin{tabular}{|c|c|}
\hline \multirow[t]{6}{*}{ Methods } & Setting: Hospital Inpatient department \\
\hline & Study design: Randomised, parallel group, multi-centre, controlled trial \\
\hline & Location: Papua New Guinea \\
\hline & Timing and duration: September 1997 to October 2000 \\
\hline & Number of centres: 3 \\
\hline & Source of funding: Roche, World Health Organization, and Royal Australasian College of Physicians \\
\hline \multirow[t]{2}{*}{ Participants } & $\begin{array}{l}\text { Children with clinical signs of meningitis, cloudy or turbid CSF with moderate or large amounts of leu- } \\
\text { cocytes and protein on dipstick testing (Multistix } 10 \mathrm{SG} \text { ) were eligible for inclusion. Children with re- } \\
\text { nal failure, congenital heart disease, who had received parenteral antibiotics for } 48 \text { hours or more in } \\
\text { the week prior to presentation or who were septic or in hypovolaemic shock were excluded from enrol- } \\
\text { ment }\end{array}$ \\
\hline & Age: $>1$ month to $<12$ years \\
\hline
\end{tabular}

Interventions Nasogastric tube fluids at $60 \%$ of maintenance fluids, (maintenance fluids defined by " $100 \mathrm{ml} / \mathrm{kg} / \mathrm{day}$
for the first $10 \mathrm{~kg}$ of body weight, $50 \mathrm{ml} / \mathrm{kg}$ for the second $10 \mathrm{~kg}$, and $20 \mathrm{ml} / \mathrm{kg}$ for over $20 \mathrm{~kg} "$ ) as expressed breast milk or other milk feed, divided into feeds given every 3 hours

versus

$100 \%$ of normal maintenance fluids (defined as above) administered intravenously (given nasogastrically in 7 children because an intravenous cannula could not be inserted) given as a solution containing $0.45 \%$ sodium chloride and $5 \%$ dextrose plus $10 \mathrm{mmol} / \mathrm{L}$ of potassium chloride per litre

Duration: 48 hours

\begin{tabular}{ll}
\hline Outcomes & $\begin{array}{l}\text { Death } \\
\text { Neurological sequelae } \\
\text { Oedema (including cerebral) } \\
\text { Serum and urinary sodium } \\
\text { Seizures }\end{array}$ \\
\hline Notes & $\begin{array}{l}260 \text { of the } 357 \text { children had confirmed bacterial meningitis. The paper states that although no bacteria } \\
\text { were isolated in the other children the diagnosis was "definitely meningitis". Numbers of children with- } \\
\text { out isolated bacteria was similar between groups } \\
\text { Severe sequelae were considered to be present if } 14 \text { days after commencing treatment there was a se- } \\
\text { vere motor deficit (marked spasticity, hemiplegia, severe hypotonia) and at least one of the following: } \\
\text { a major sensory deficit (inability to fix and follow in an age-appropriate way or no response to sound), } \\
\text { persistent convulsions or coma } \\
\text { All children received phenobarbitone, and received oxygen for the first } 48 \text { hours. The 1st } 150 \text { children } \\
\text { received chloramphenicol, the rest ceftriaxone. Mechanical ventilation was not available }\end{array}$ \\
\hline
\end{tabular}

\section{Risk of bias}

\begin{tabular}{lll}
\hline Bias & Authors' judgement & Support for judgement \\
\hline $\begin{array}{l}\text { Random sequence genera- } \\
\text { tion (selection bias) }\end{array}$ & Low risk & Adequate, with comparable treatment and control groups at entry \\
\hline
\end{tabular}


Duke 2002 (Continued)

Allocation concealment Low risk Adequate, using sealed envelopes
(selection bias)

Blinding of participants High risk Clearly not
and personnel (perfor-

\begin{tabular}{lll}
\hline $\begin{array}{l}\text { Blinding of outcome as- } \\
\text { sessment (detection bias) } \\
\text { All outcomes }\end{array}$ & Low risk & Low risk for outcomes of death and acute severe neurological sequelae \\
\hline $\begin{array}{l}\text { Incomplete outcome data } \\
\begin{array}{l}\text { (attrition bias) } \\
\text { All outcomes }\end{array}\end{array}$ & Low risk & $\begin{array}{l}\text { Adequate overall with } 11 \text { of } 357 \text { excluded post-randomisation as found not } \\
\text { to have meningitis. However, over } 10 \% \text { of participants lost to follow-up at } 3 \\
\text { months }\end{array}$
\end{tabular}

\begin{tabular}{lll}
\hline $\begin{array}{l}\text { Selective reporting (re- } \\
\text { porting bias) }\end{array}$ & Low risk & $\begin{array}{l}\text { Adequate, with a good range of appropriate outcomes reported. 14 days is } \\
\text { somewhat early to judge whether severe sequelae were present }\end{array}$ \\
\hline Other bias & Low risk & A large and well-described study \\
\hline
\end{tabular}

\section{Powell 1990}

\begin{tabular}{|c|c|}
\hline \multirow[t]{5}{*}{ Methods } & Setting: Hospital Inpatient department \\
\hline & Study design: Randomised, parallel group, single-centre, controlled trial \\
\hline & Location: USA \\
\hline & Timing and duration: July 1985 to June 1988 \\
\hline & Source of funding: Hoffmann-La Roche, Praxis Biologies, National Institute of Health \\
\hline \multirow[t]{2}{*}{ Participants } & $\begin{array}{l}\text { Previously healthy children with a clinical diagnosis of meningitis, and confirmed by CSF cytology and } \\
\text { by chemical studies were eligible for inclusion. Children with central nervous system disease, renal dis- } \\
\text { ease, who were prematurely delivered (at less than } 36 \text { weeks gestation), who have congestive heart } \\
\text { failure, chronic pulmonary disease, malignancy, immunodeficiency, hepatic disease, or were on mor- } \\
\text { phine/phenobarbitone/phenytoin/dexamethazone or lithium were excluded from enrolment }\end{array}$ \\
\hline & Age: 3 months to 16 years \\
\hline \multirow[t]{4}{*}{ Interventions } & $\begin{array}{l}\text { 2/3 maintenance fluids (maintenance defined as } 100 \mathrm{ml} / \mathrm{kg} \text { for the first } 10 \mathrm{~kg} \text { of body weight, plus } 50 \\
\mathrm{ml} / \mathrm{kg} \text { for the next } 10 \mathrm{~kg} \text { ( } 10 \mathrm{~kg} \text { to } 20 \mathrm{~kg} \text { ), plus } 20 \mathrm{ml} / \mathrm{kg} \text { for each kilogram in excess of } 20 \mathrm{~kg} \text { ) }\end{array}$ \\
\hline & versus \\
\hline & $\begin{array}{l}\text { Full maintenance fluids (as defined above), plus replacement fluids for any estimated deficit over } 24 \\
\text { hours. Rehydration was begun by administering } 10 \mathrm{ml} / \mathrm{kg} \text { or } 15 \mathrm{ml} / \mathrm{kg} \text { by rapid intravenous infusion }\end{array}$ \\
\hline & Duration: 24 hours \\
\hline Outcomes & $\begin{array}{l}\text { Serum osmolality } \\
\text { Serum sodium }\end{array}$ \\
\hline Notes & $\begin{array}{l}13 \text { children with bacterial meningitis and } 6 \text { with aseptic meningitis were enrolled. Results were report- } \\
\text { ed separately. However, the initially pathology of the } 6 \text { exclusions was not documented }\end{array}$ \\
\hline
\end{tabular}

\section{Risk of bias}

Fluid therapy for acute bacterial meningitis (Review) 
Powell 1990 (Continued)

Bias Authors' judgement Support for judgement

Random sequence genera- Unclear risk Not described
tion (selection bias)

\begin{tabular}{lll}
\hline Allocation concealment $\quad$ Low risk $\quad$ Adequate, using sealed envelopes
\end{tabular}

(selection bias)

Blinding of participants $\quad$ High risk
and personnel (perfor-

\begin{tabular}{|c|c|c|}
\hline $\begin{array}{l}\text { Blinding of outcome as- } \\
\text { sessment (detection bias) } \\
\text { All outcomes }\end{array}$ & Low risk & Low risk for outcomes of death and acute severe neurological sequelae \\
\hline $\begin{array}{l}\text { Incomplete outcome data } \\
\text { (attrition bias) } \\
\text { All outcomes }\end{array}$ & High risk & $\begin{array}{l}\text { Did not account for all participants. } 5 \text { out of } 24 \text { participants were not included } \\
\text { in final analysis }\end{array}$ \\
\hline $\begin{array}{l}\text { Selective reporting (re- } \\
\text { porting bias) }\end{array}$ & High risk & $\begin{array}{l}\text { Reporting of outcome data not adequate. No reporting of important outcomes } \\
\text { of death, intact survival }\end{array}$ \\
\hline Other bias & High risk & Most eligible participants not randomised. Poor reporting of details of study \\
\hline
\end{tabular}

Singhi 1995

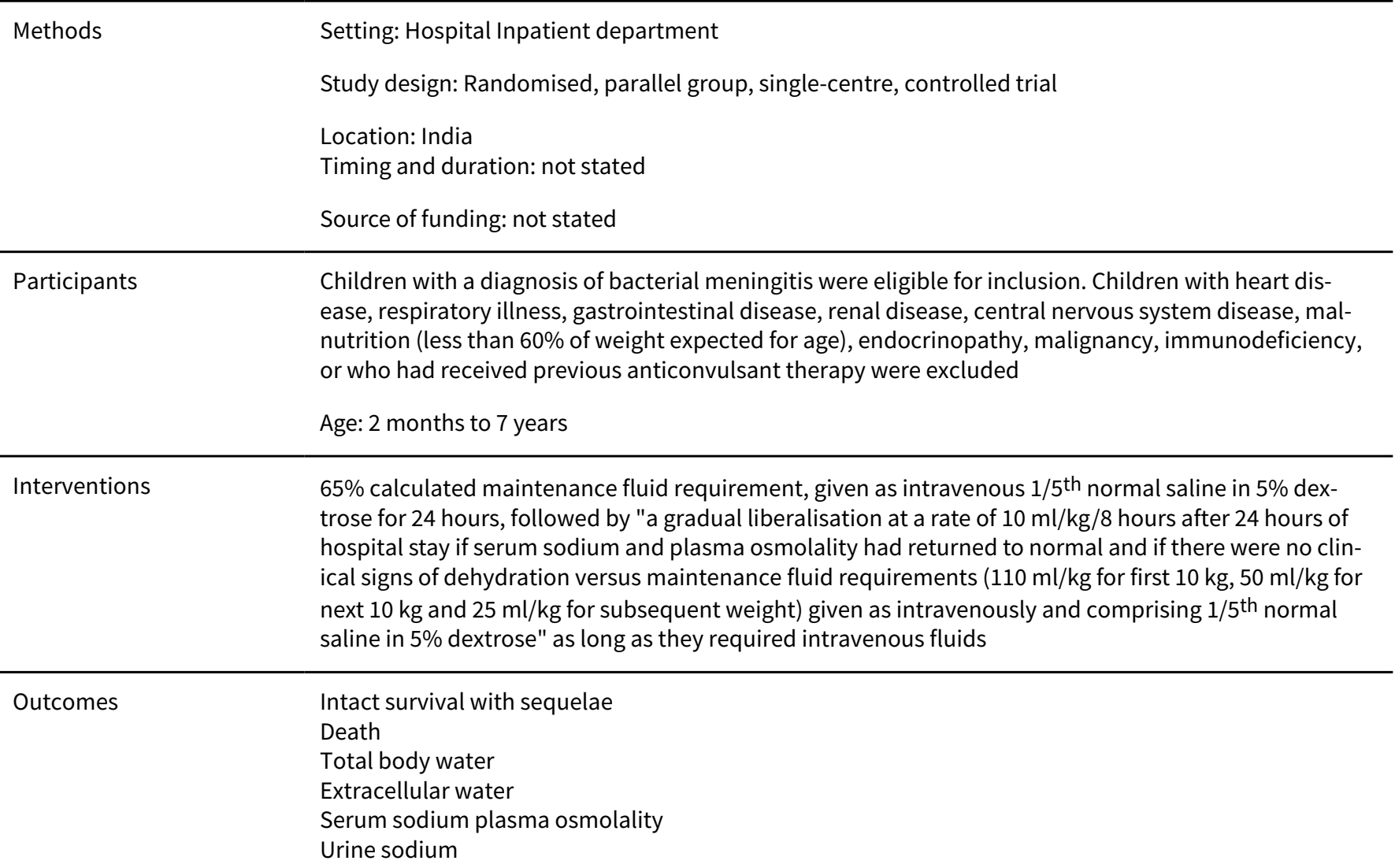


Singhi 1995 (Continued)

Urine osmolality

Notes Trial was stopped prematurely "when a trend toward poor outcome in the restricted-fluid group became obvious"

\section{Risk of bias}

\begin{tabular}{|c|c|c|}
\hline Bias & Authors' judgement & Support for judgement \\
\hline $\begin{array}{l}\text { Random sequence genera- } \\
\text { tion (selection bias) }\end{array}$ & Unclear risk & $\begin{array}{l}\text { Use of a list or table. Treatment and control groups were comparable at study } \\
\text { entry }\end{array}$ \\
\hline $\begin{array}{l}\text { Allocation concealment } \\
\text { (selection bias) }\end{array}$ & Unclear risk & Unclear, with the use of a list or table \\
\hline $\begin{array}{l}\text { Blinding of participants } \\
\text { and personnel (perfor- } \\
\text { mance bias) } \\
\text { All outcomes }\end{array}$ & High risk & Clearly neither participant's nor treatment providers blinded \\
\hline $\begin{array}{l}\text { Blinding of outcome as- } \\
\text { sessment (detection bias) } \\
\text { All outcomes }\end{array}$ & Low risk & $\begin{array}{l}\text { Clearly neither outcome assessors, participants nor treatment providers blind- } \\
\text { ed }\end{array}$ \\
\hline $\begin{array}{l}\text { Incomplete outcome data } \\
\text { (attrition bias) } \\
\text { All outcomes }\end{array}$ & Low risk & Appeared to account for all participants \\
\hline $\begin{array}{l}\text { Selective reporting (re- } \\
\text { porting bias) }\end{array}$ & High risk & $\begin{array}{l}\text { Mixed neurological outcomes and complications, so some important out- } \\
\text { comes unavailable }\end{array}$ \\
\hline Other bias & High risk & $\begin{array}{l}\text { Study was stopped prematurely, with no a priori stopping rules, with a "trend } \\
\text { towards poor outcome" in one group }\end{array}$ \\
\hline
\end{tabular}

CSF: cerebrospinal fluid

Characteristics of excluded studies [ordered by study ID]

\begin{tabular}{ll}
\hline Study & Reason for exclusion \\
\hline Berkley 2004 & Interventions and comparators not relevant \\
\hline Brown 1994 & Not a RCT \\
\hline Duke 1998 & Not a RCT \\
\hline Floret 1999 & Not a RCT \\
\hline Maitland 2013 & Sufficient data on culture-positive bacterial meningitis not available \\
\hline Pelkonen 2011 & Intervention not relevant \\
\hline Roine 2014 & Not a RCT; used for reference searching for a trial mentioned in abstract which was found to be \\
\hline van Paridon 2015 & Not a RCT \\
\hline \hline
\end{tabular}

Fluid therapy for acute bacterial meningitis (Review)

Copyright $\odot 2016$ The Cochrane Collaboration. Published by John Wiley \& Sons, Ltd. 
$\mathrm{RCT}$ : randomised controlled trial

\section{DATA AND ANALYSES}

\section{Comparison 1. Maintenance fluids versus restricted fluids}

\begin{tabular}{|c|c|c|c|c|}
\hline Outcome or subgroup title & No. of studies & $\begin{array}{l}\text { No. of partici- } \\
\text { pants }\end{array}$ & Statistical method & Effect size \\
\hline 1 Death & 2 & & Risk Ratio (M-H, Fixed, 95\% Cl) & Subtotals only \\
\hline 1.1 All participants & 2 & 407 & Risk Ratio (M-H, Fixed, 95\% CI) & $0.82[0.53,1.27]$ \\
\hline $\begin{array}{l}\text { 1.2 Participants with hypona- } \\
\text { traemia }\end{array}$ & 1 & 26 & Risk Ratio (M-H, Fixed, 95\% Cl) & $0.15[0.01,2.50]$ \\
\hline $\begin{array}{l}\text { 1.3 Participants without hy- } \\
\text { ponatraemia }\end{array}$ & 1 & 24 & Risk Ratio (M-H, Fixed, 95\% Cl) & $0.79[0.16,3.90]$ \\
\hline 2 Severe neurological sequelae & 2 & & Risk Ratio (M-H, Fixed, 95\% Cl) & Subtotals only \\
\hline $\begin{array}{l}2.1 \text { Acute (within the first } 4 \\
\text { weeks) }\end{array}$ & 2 & 407 & Risk Ratio (M-H, Fixed, 95\% Cl) & $0.67[0.41,1.08]$ \\
\hline $\begin{array}{l}2.2 \text { Chronic (after the first } 4 \\
\text { weeks) }\end{array}$ & 1 & 351 & Risk Ratio (M-H, Fixed, 95\% Cl) & $0.42[0.20,0.89]$ \\
\hline $\begin{array}{l}\text { 2.3 Participants without hy- } \\
\text { ponatraemia }\end{array}$ & 1 & 24 & Risk Ratio (M-H, Fixed, 95\% Cl) & $0.59[0.13,2.64]$ \\
\hline $\begin{array}{l}\text { 2.4 Participants with hypona- } \\
\text { traemia }\end{array}$ & 1 & 26 & Risk Ratio (M-H, Fixed, 95\% Cl) & $0.91[0.34,2.47]$ \\
\hline $\begin{array}{l}3 \text { Mild to moderate neurological } \\
\text { sequelae }\end{array}$ & 1 & & Risk Ratio (M-H, Fixed, 95\% Cl) & $\begin{array}{l}\text { Totals not select- } \\
\text { ed }\end{array}$ \\
\hline 3.1 At 14 days & 1 & & Risk Ratio (M-H, Fixed, 95\% Cl) & $0.0[0.0,0.0]$ \\
\hline 4 Hemiparesis/hemiplegia & 1 & & Risk Ratio (M-H, Fixed, 95\% Cl) & $\begin{array}{l}\text { Totals not select- } \\
\text { ed }\end{array}$ \\
\hline 4.1 At 14 days & 1 & & Risk Ratio (M-H, Fixed, 95\% Cl) & $0.0[0.0,0.0]$ \\
\hline 5 Spasticity & 1 & & Risk Ratio (M-H, Fixed, 95\% Cl) & $\begin{array}{l}\text { Totals not select- } \\
\text { ed }\end{array}$ \\
\hline 5.1 At 14 days & 1 & & Risk Ratio (M-H, Fixed, 95\% Cl) & $0.0[0.0,0.0]$ \\
\hline 6 Seizures & 1 & & Risk Ratio (M-H, Fixed, 95\% Cl) & $\begin{array}{l}\text { Totals not select- } \\
\text { ed }\end{array}$ \\
\hline 6.1 Within the first 72 hours & 1 & & Risk Ratio (M-H, Fixed, 95\% Cl) & $0.0[0.0,0.0]$ \\
\hline 6.2 At 14 days & 1 & & Risk Ratio (M-H, Fixed, 95\% Cl) & $0.0[0.0,0.0]$ \\
\hline
\end{tabular}




\begin{tabular}{|c|c|c|c|c|}
\hline Outcome or subgroup title & No. of studies & $\begin{array}{l}\text { No. of partici- } \\
\text { pants }\end{array}$ & Statistical method & Effect size \\
\hline 7 Visual impairment & 1 & & Risk Ratio (M-H, Fixed, 95\% Cl) & $\begin{array}{l}\text { Totals not select- } \\
\text { ed }\end{array}$ \\
\hline 7.1 At 14 days & 1 & & Risk Ratio (M-H, Fixed, 95\% Cl) & $0.0[0.0,0.0]$ \\
\hline 8 No response to sound & 1 & & Risk Ratio (M-H, Fixed, 95\% Cl) & $\begin{array}{l}\text { Totals not select- } \\
\text { ed }\end{array}$ \\
\hline 8.1 At 14 days & 1 & & Risk Ratio (M-H, Fixed, 95\% Cl) & $0.0[0.0,0.0]$ \\
\hline 9 Oedema & 1 & & Risk Ratio (M-H, Fixed, 95\% Cl) & $\begin{array}{l}\text { Totals not select- } \\
\text { ed }\end{array}$ \\
\hline 9.1 Acute facial oedema & 1 & & Risk Ratio (M-H, Fixed, 95\% Cl) & $0.0[0.0,0.0]$ \\
\hline 9.2 Acute pulmonary oedema & 1 & & Risk Ratio (M-H, Fixed, 95\% Cl) & $0.0[0.0,0.0]$ \\
\hline 9.3 Acute hydrocephalus & 1 & & Risk Ratio (M-H, Fixed, 95\% Cl) & $0.0[0.0,0.0]$ \\
\hline $\begin{array}{l}10 \text { Total body water - fall after } \\
48 \text { hours }\end{array}$ & 1 & & Mean Difference (IV, Fixed, 95\% CI) & $\begin{array}{l}\text { Totals not select- } \\
\text { ed }\end{array}$ \\
\hline $\begin{array}{l}10.1 \text { Participants without hy- } \\
\text { ponatraemia }\end{array}$ & 1 & & Mean Difference (IV, Fixed, 95\% CI) & $0.0[0.0,0.0]$ \\
\hline $\begin{array}{l}10.2 \text { Participants with hypona- } \\
\text { traemia }\end{array}$ & 1 & & Mean Difference (IV, Fixed, 95\% CI) & $0.0[0.0,0.0]$ \\
\hline $\begin{array}{l}11 \text { Extracellular water - fall after } \\
48 \text { hours }\end{array}$ & 1 & & Mean Difference (IV, Fixed, 95\% CI) & $\begin{array}{l}\text { Totals not select- } \\
\text { ed }\end{array}$ \\
\hline $\begin{array}{l}11.1 \text { Participants without hy- } \\
\text { ponatraemia }\end{array}$ & 1 & & Mean Difference (IV, Fixed, 95\% CI) & $0.0[0.0,0.0]$ \\
\hline $\begin{array}{l}11.2 \text { Participants with hypona- } \\
\text { traemia }\end{array}$ & 1 & & Mean Difference (IV, Fixed, 95\% CI) & $0.0[0.0,0.0]$ \\
\hline 12 Serum sodium & 2 & & Mean Difference (IV, Fixed, 95\% CI) & $\begin{array}{l}\text { Totals not select- } \\
\text { ed }\end{array}$ \\
\hline 12.1 All participants (24 hours) & 1 & & Mean Difference (IV, Fixed, 95\% CI) & $0.0[0.0,0.0]$ \\
\hline $\begin{array}{l}\text { 12.2 Participants with hypona- } \\
\text { traemia ( } 48 \text { hours) }\end{array}$ & 1 & & Mean Difference (IV, Fixed, 95\% CI) & $0.0[0.0,0.0]$ \\
\hline $\begin{array}{l}12.3 \text { Participants without hy- } \\
\text { ponatraemia ( } 48 \text { hours) }\end{array}$ & 1 & & Mean Difference (IV, Fixed, 95\% CI) & $0.0[0.0,0.0]$ \\
\hline $\begin{array}{l}12.4 \text { Change from baseline at } 48 \\
\text { hours - without hyponatraemia }\end{array}$ & 1 & & Mean Difference (IV, Fixed, 95\% CI) & $0.0[0.0,0.0]$ \\
\hline $\begin{array}{l}12.5 \text { Change from baseline at } 48 \\
\text { hours - with hyponatraemia }\end{array}$ & 1 & & Mean Difference (IV, Fixed, 95\% CI) & $0.0[0.0,0.0]$ \\
\hline
\end{tabular}




\begin{tabular}{|c|c|c|c|c|}
\hline Outcome or subgroup title & No. of studies & $\begin{array}{l}\text { No. of partici- } \\
\text { pants }\end{array}$ & Statistical method & Effect size \\
\hline 13 Urinary sodium & 1 & & Mean Difference (IV, Fixed, 95\% CI) & $\begin{array}{l}\text { Totals not select- } \\
\text { ed }\end{array}$ \\
\hline $\begin{array}{l}\text { 13.1 Participants without hy- } \\
\text { ponatraemia ( } 48 \text { hours) }\end{array}$ & 1 & & Mean Difference (IV, Fixed, 95\% CI) & $0.0[0.0,0.0]$ \\
\hline $\begin{array}{l}\text { 13.2 Participants with hypona- } \\
\text { traemia ( } 48 \text { hours) }\end{array}$ & 1 & & Mean Difference (IV, Fixed, 95\% CI) & $0.0[0.0,0.0]$ \\
\hline $\begin{array}{l}13.3 \text { Change from baseline at } 48 \\
\text { hours - without hyponatraemia }\end{array}$ & 1 & & Mean Difference (IV, Fixed, 95\% CI) & $0.0[0.0,0.0]$ \\
\hline $\begin{array}{l}13.4 \text { Change from baseline at } 48 \\
\text { hours - with hyponatraemia }\end{array}$ & 1 & & Mean Difference (IV, Fixed, 95\% CI) & $0.0[0.0,0.0]$ \\
\hline $\begin{array}{l}14 \text { Plasma osmolality - change } \\
\text { after } 48 \text { hours }\end{array}$ & 1 & & Mean Difference (IV, Fixed, 95\% CI) & $\begin{array}{l}\text { Totals not select- } \\
\text { ed }\end{array}$ \\
\hline $\begin{array}{l}\text { 14.1 Participants without hy- } \\
\text { ponatraemia }\end{array}$ & 1 & & Mean Difference (IV, Fixed, 95\% CI) & $0.0[0.0,0.0]$ \\
\hline $\begin{array}{l}14.2 \text { Participants with hypona- } \\
\text { traemia }\end{array}$ & 1 & & Mean Difference (IV, Fixed, 95\% CI) & $0.0[0.0,0.0]$ \\
\hline
\end{tabular}

Analysis 1.1. Comparison 1 Maintenance fluids versus restricted fluids, Outcome 1 Death.

\begin{tabular}{|c|c|c|c|c|c|}
\hline Study or subgroup & $\begin{array}{c}\text { Mainte- } \\
\text { nance fluids } \\
n / N \\
\end{array}$ & $\begin{array}{c}\text { Restrict- } \\
\text { ed fluids } \\
n / N\end{array}$ & $\begin{array}{c}\text { Risk Ratio } \\
\text { M-H, Fixed, 95\% Cl }\end{array}$ & Weight & $\begin{array}{c}\text { Risk Ratio } \\
\text { M-H, Fixed, } 95 \% \mathrm{Cl}\end{array}$ \\
\hline \multicolumn{6}{|l|}{ 1.1.1 All participants } \\
\hline Duke 2002 & $29 / 181$ & $31 / 176$ & & $83.61 \%$ & $0.91[0.57,1.44]$ \\
\hline Singhi 1995 & $2 / 22$ & $7 / 28$ & & $16.39 \%$ & $0.36[0.08,1.58]$ \\
\hline Subtotal $(95 \% \mathrm{CI})$ & 203 & 204 & & $100 \%$ & $0.82[0.53,1.27]$ \\
\hline \multicolumn{6}{|c|}{ Heterogeneity: $\mathrm{Tau}^{2}=0 ; \mathrm{Chi}^{2}=1.37, \mathrm{df}=1(\mathrm{P}=0.24) ; \mathrm{I}^{2}=27.05 \%$} \\
\hline \multicolumn{6}{|c|}{ Test for overall effect: $Z=0.89(P=0.37)$} \\
\hline \multicolumn{6}{|c|}{ 1.1.2 Participants with hyponatraemia } \\
\hline Singhi 1995 & $0 / 11$ & $4 / 15$ & & $100 \%$ & $0.15[0.01,2.5]$ \\
\hline Subtotal $(95 \% \mathrm{Cl})$ & 11 & 15 & & $100 \%$ & $0.15[0.01,2.5]$ \\
\hline \multicolumn{6}{|c|}{ Heterogeneity: Not applicable } \\
\hline \multicolumn{6}{|c|}{ Test for overall effect: $Z=1.33(P=0.19)$} \\
\hline \multicolumn{6}{|c|}{ 1.1.3 Participants without hyponatraemia } \\
\hline Singhi 1995 & $2 / 11$ & $3 / 13$ & - & $100 \%$ & $0.79[0.16,3.9]$ \\
\hline Subtotal $(95 \% \mathrm{Cl})$ & 11 & 13 & & $100 \%$ & $0.79[0.16,3.9]$ \\
\hline \multicolumn{6}{|c|}{ Total events: 2 (Maintenance fluids), 3 (Restricted fluids) } \\
\hline \multicolumn{6}{|c|}{ Heterogeneity: Not applicable } \\
\hline Test for overall effect & & & & & \\
\hline
\end{tabular}


Analysis 1.2. Comparison 1 Maintenance fluids versus restricted fluids, Outcome 2 Severe neurological sequelae.

\begin{tabular}{|c|c|c|c|c|c|}
\hline Study or subgroup & $\begin{array}{c}\text { Mainte- } \\
\text { nance fluids } \\
\mathbf{n} / \mathbf{N} \\
\end{array}$ & $\begin{array}{c}\text { Restrict- } \\
\text { ed fluids } \\
n / N \\
\end{array}$ & $\begin{array}{c}\text { Risk Ratio } \\
\text { M-H, Fixed, 95\% Cl }\end{array}$ & Weight & $\begin{array}{c}\text { Risk Ratio } \\
\text { M-H, Fixed, } 95 \% \mathrm{Cl}\end{array}$ \\
\hline \multicolumn{6}{|c|}{ 1.2.1 Acute (within the first 4 weeks) } \\
\hline Duke 2002 & $17 / 181$ & $26 / 176$ & & $74.97 \%$ & $0.64[0.36,1.13]$ \\
\hline Singhi 1995 & $6 / 22$ & $10 / 28$ & & $25.03 \%$ & $0.76[0.33,1.78]$ \\
\hline Subtotal $(95 \% \mathrm{CI})$ & 203 & 204 & & $100 \%$ & $0.67[0.41,1.08]$ \\
\hline \multicolumn{6}{|c|}{ Heterogeneity: $\mathrm{Tau}^{2}=0 ; \mathrm{Chi}^{2}=0.12, \mathrm{df}=1(\mathrm{P}=0.72) ; \mathrm{I}^{2}=0 \%$} \\
\hline \multicolumn{6}{|c|}{ Test for overall effect: $Z=1.66(P=0.1)$} \\
\hline \multicolumn{6}{|c|}{ 1.2.2 Chronic (after the first 4 weeks) } \\
\hline Duke 2002 & $9 / 177$ & $21 / 174$ & & $100 \%$ & $0.42[0.2,0.89]$ \\
\hline Subtotal $(95 \% \mathrm{Cl})$ & 177 & 174 & & $100 \%$ & $0.42[0.2,0.89]$ \\
\hline \multicolumn{6}{|c|}{ Heterogeneity: Not applicable } \\
\hline \multicolumn{6}{|c|}{ Test for overall effect: $Z=2.25(P=0.02)$} \\
\hline \multicolumn{6}{|c|}{ 1.2.3 Participants without hyponatraemia } \\
\hline Singhi 1995 & $2 / 11$ & $4 / 13$ & & $100 \%$ & $0.59[0.13,2.64]$ \\
\hline Subtotal $(95 \% \mathrm{CI})$ & 11 & 13 & & $100 \%$ & $0.59[0.13,2.64]$ \\
\hline \multicolumn{6}{|c|}{ Total events: 2 (Maintenance fluids), 4 (Restricted fluids) } \\
\hline \multicolumn{6}{|c|}{ Heterogeneity: Not applicable } \\
\hline \multicolumn{6}{|c|}{ Test for overall effect: $Z=0.69(P=0.49)$} \\
\hline \multicolumn{6}{|c|}{ 1.2.4 Participants with hyponatraemia } \\
\hline Singhi 1995 & $4 / 11$ & $6 / 15$ & - & $100 \%$ & $0.91[0.34,2.47]$ \\
\hline Subtotal $(95 \% \mathrm{Cl})$ & 11 & 15 & & $100 \%$ & $0.91[0.34,2.47]$ \\
\hline \multicolumn{6}{|c|}{ Heterogeneity: Not applicable } \\
\hline Test for overall effect & & & & & \\
\hline
\end{tabular}

Analysis 1.3. Comparison 1 Maintenance fluids versus restricted fluids, Outcome 3 Mild to moderate neurological sequelae.

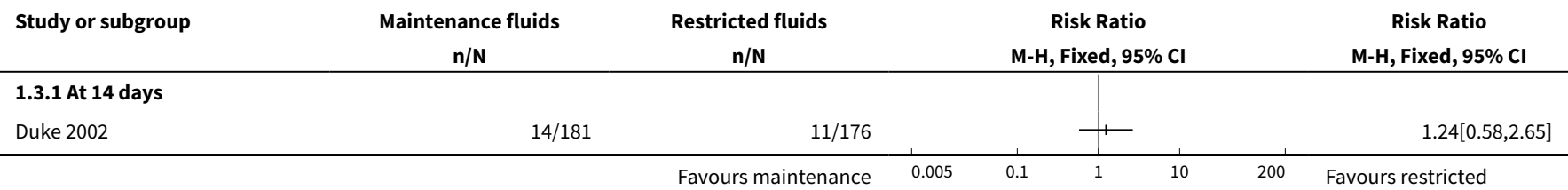


Analysis 1.4. Comparison 1 Maintenance fluids versus restricted fluids, Outcome 4 Hemiparesis/hemiplegia.

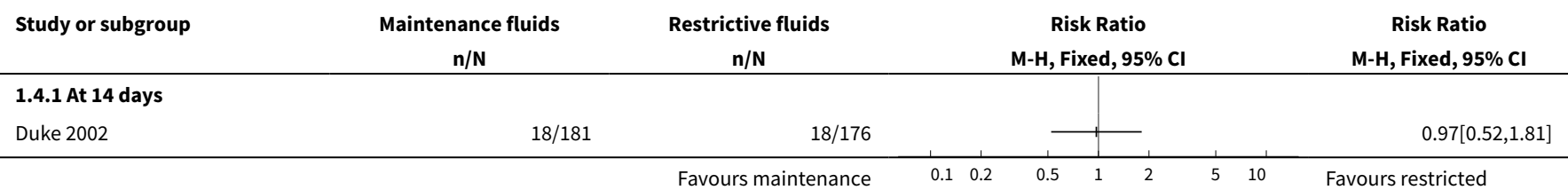

Analysis 1.5. Comparison 1 Maintenance fluids versus restricted fluids, Outcome 5 Spasticity.

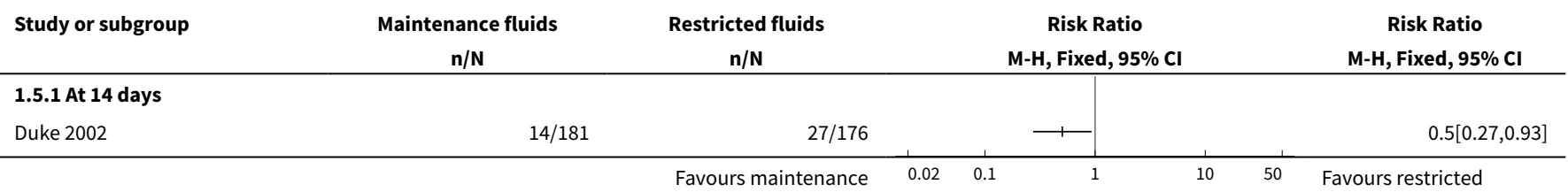

Analysis 1.6. Comparison 1 Maintenance fluids versus restricted fluids, Outcome 6 Seizures.

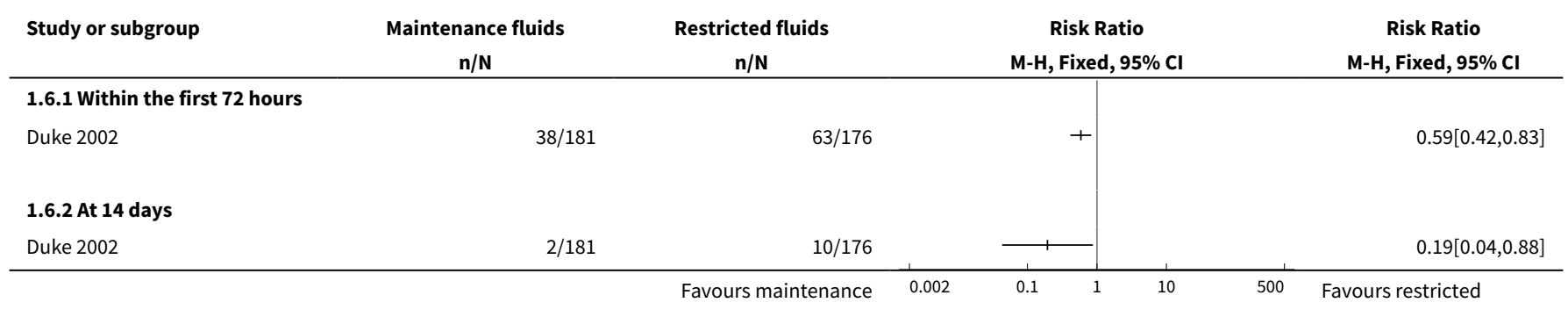

Analysis 1.7. Comparison 1 Maintenance fluids versus restricted fluids, Outcome 7 Visual impairment.

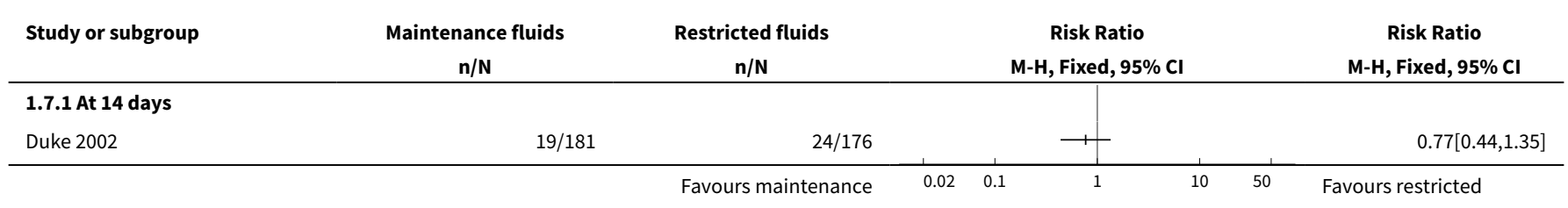

Analysis 1.8. Comparison 1 Maintenance fluids versus restricted fluids, Outcome 8 No response to sound.

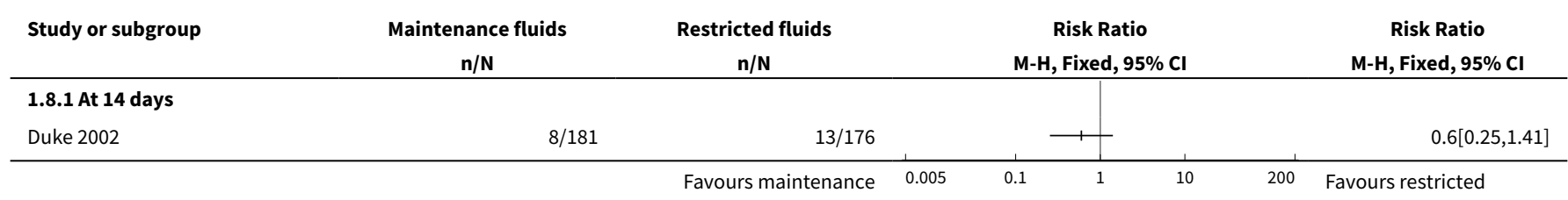


Analysis 1.9. Comparison 1 Maintenance fluids versus restricted fluids, Outcome 9 Oedema.

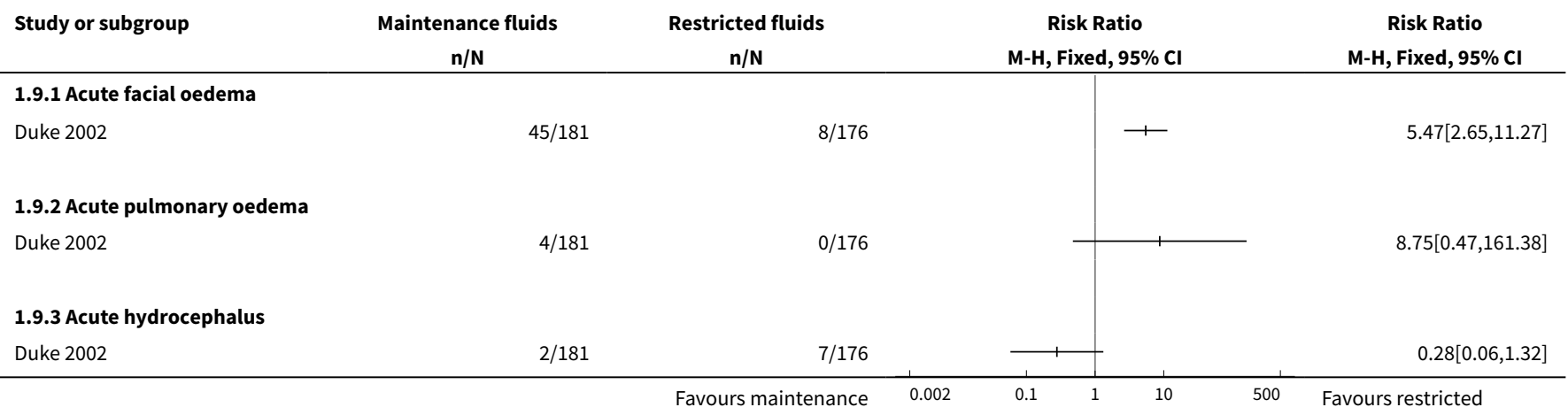

Analysis 1.10. Comparison 1 Maintenance fluids versus restricted fluids, Outcome 10 Total body water - fall after 48 hours.

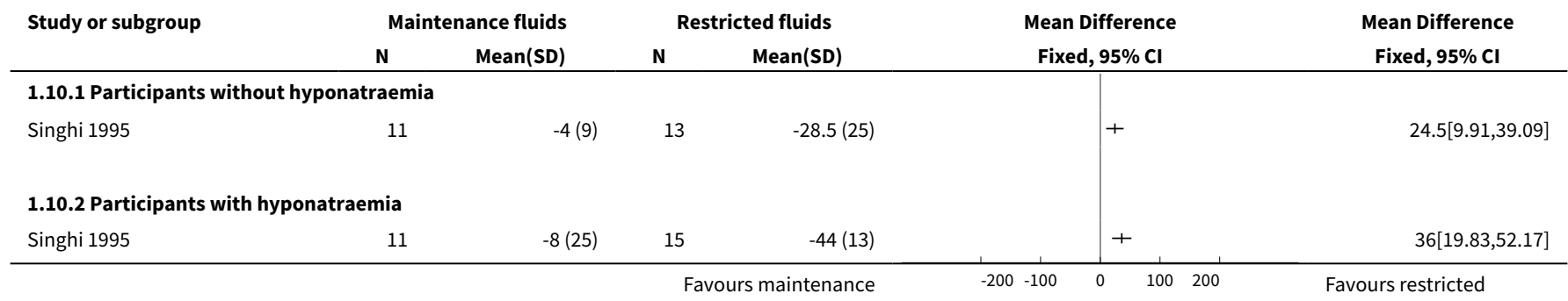

\section{Analysis 1.11. Comparison 1 Maintenance fluids versus restricted} fluids, Outcome 11 Extracellular water - fall after 48 hours.

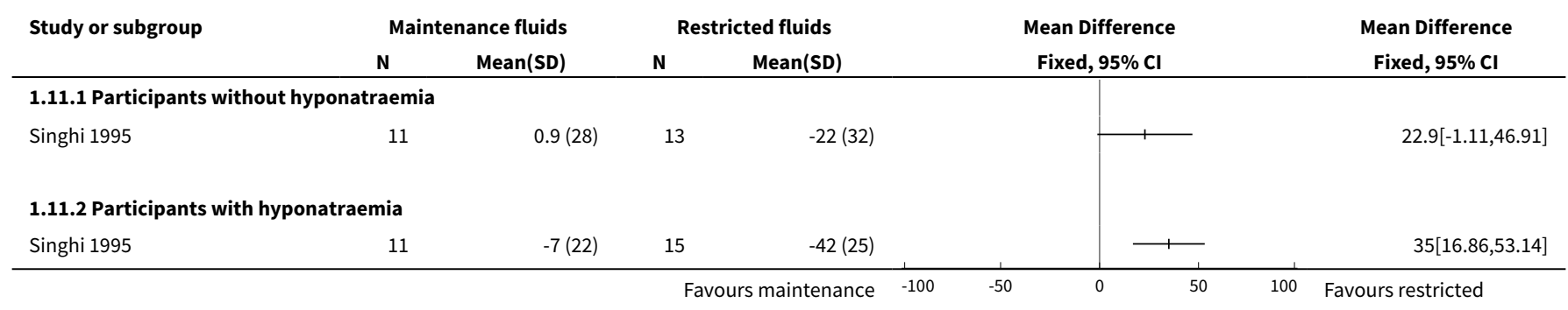

Analysis 1.12. Comparison 1 Maintenance fluids versus restricted fluids, Outcome 12 Serum sodium.

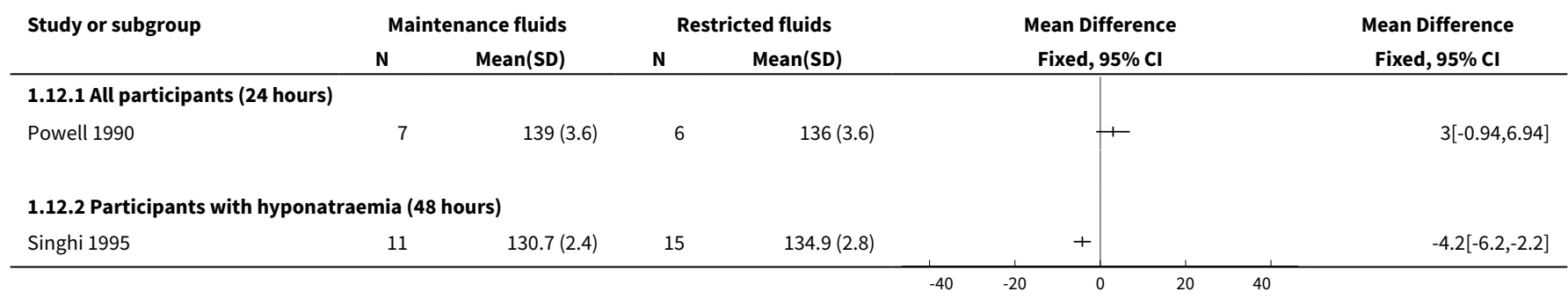




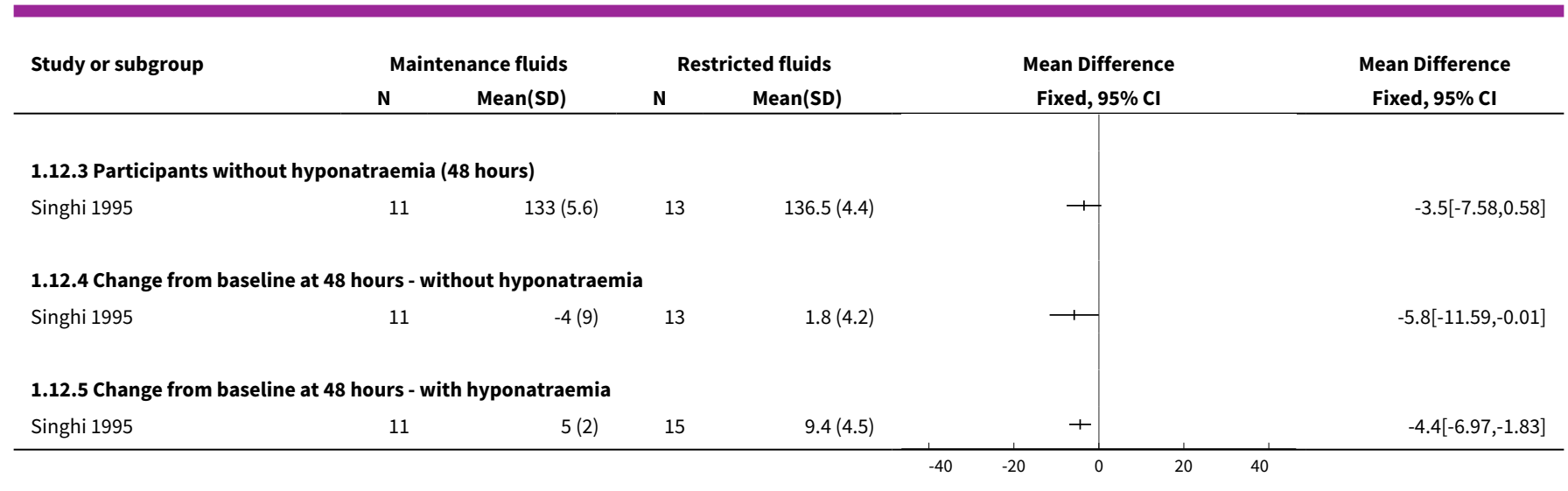

Analysis 1.13. Comparison 1 Maintenance fluids versus restricted fluids, Outcome 13 Urinary sodium.

\begin{tabular}{|c|c|c|c|c|c|c|}
\hline \multirow[t]{2}{*}{ Study or subgroup } & \multicolumn{2}{|c|}{ Maintenance fluids } & \multicolumn{2}{|c|}{ Restricted fluids } & \multirow{2}{*}{$\begin{array}{c}\text { Mean Difference } \\
\text { Fixed, } 95 \% \mathrm{Cl}\end{array}$} & \multirow{2}{*}{$\begin{array}{c}\text { Mean Difference } \\
\text { Fixed, } 95 \% \mathrm{Cl}\end{array}$} \\
\hline & $\mathbf{N}$ & Mean(SD) & $\mathbf{N}$ & Mean(SD) & & \\
\hline \multicolumn{7}{|c|}{ 1.13.1 Participants without hyponatraemia (48 hours) } \\
\hline Singhi 1995 & 11 & $24(20)$ & 13 & $38(24)$ & + & $-14[-31.6,3.6]$ \\
\hline \multicolumn{7}{|c|}{ 1.13.2 Participants with hyponatraemia (48 hours) } \\
\hline Singhi 1995 & 11 & $22(6)$ & 15 & $43(25)$ & + & $-21[-34.14,-7.86]$ \\
\hline \multicolumn{7}{|c|}{ 1.13.3 Change from baseline at 48 hours - without hyponatraemia } \\
\hline Singhi 1995 & 11 & $-7(16)$ & 13 & $-8(17)$ & + & $1[-12.22,14.22]$ \\
\hline \multicolumn{7}{|c|}{ 1.13.4 Change from baseline at 48 hours - with hyponatraemia } \\
\hline Singhi 1995 & 11 & $-24(8)$ & 15 & $-24(15)$ & + & $0[-8.94,8.94]$ \\
\hline
\end{tabular}

\section{Analysis 1.14. Comparison 1 Maintenance fluids versus restricted fluids, Outcome 14 Plasma osmolality - change after 48 hours.}

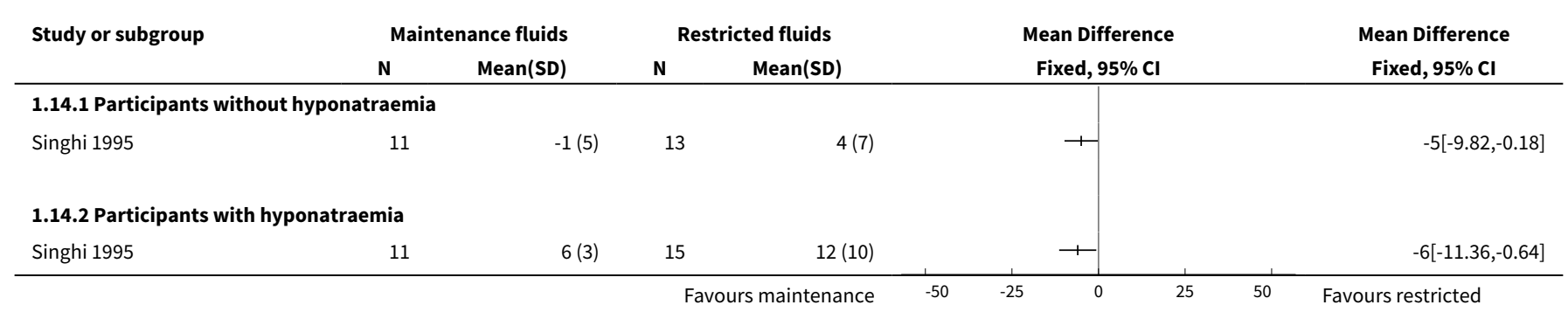

\section{APPENDICES}

\section{Appendix 1. CENTRAL Search Strategy 2016 Update}

\#1 [mh Meningitis] OR [mh "Meningitis, Bacterial"] OR [mh "Meningococcal Infections"] OR [mh "Pneumococcal Infections"] OR [mh "Neisseria meningitidis"] OR [mh "Escherichia coli Infections"] OR ("escherichia coli" or "e coli"):ti,ab OR [mh "Listeria monocytogenes"] or 
[mh "Meningitis, Listeria"] OR "listeria monocytogenes":ti,ab OR [mh "Haemophilus influenzae type b"] OR [mh "haemophilus infections"] or [mh "meningitis, haemophilus"] OR ((haemophilus or hemophilus or hib) NEAR2 (mening* or infect*)):ti,ab OR [mh "Streptococcus agalactiae"] OR ("streptococcus group b" or "streptococcus agalactiae"):ti,ab OR (meningit* or meningococ*):ti,ab

\#2 [mh "Fluid Therapy"] OR [mh "Body Fluids"] OR fluid*:ti,ab OR [mh solutions] or [mh "hypertonic solutions"] or [mh "isotonic solutions"] or [mh "rehydration solutions"] OR solution*:ti,ab OR (rehydrat* or dehydrat* or hydrat*):ti,ab OR [mh "Sodium Chloride"] OR (saline* or sodium*):ti,ab OR hyponatr*:ti,ab OR [mh "Infusions, Parenteral"] OR (parenteral NEAR2 (infusion* or solution*)):ti,ab OR [mh "Water Deprivation"] OR [mh "Water-Electrolyte Balance"] OR [mh "Water-Electrolyte Imbalance"] OR electrolyt*:ti,ab OR [mh Albumins] OR albumin*:ti,ab OR [mh Plasma] OR [mh "Plasma Substitutes"] OR plasma*:ti,ab OR (starch* or dextran* or gelofus* or haemacc* or hemacc*):ti,ab

\section{\#3 \#1 AND \#2}

\section{Appendix 2. MEDLINE Search Strategy 2016 Update}

S1 ( Meningitis/ OR exp Meningitis, Bacterial/ OR exp Meningococcal Infections/ OR exp Pneumococcal Infections/ OR exp Neisseria meningitidis/ OR exp Escherichia coli Infections/ OR ( ("escherichia coli" or "e coli").tw. ) OR ( Listeria monocytogenes/ or Meningitis, Listeria/) OR "listeria monocytogenes".tw. OR Haemophilus influenzae type b/ OR ( haemophilus infections/ or meningitis, haemophilus/) OR ( ((haemophilus or hemophilus or hib) adj2 (mening* or infect*)).tw. )) OR Streptococcus agalactiae/ OR ( ("streptococcus group b" or "streptococcus agalactiae").tw. ) OR ( (meningit* or meningococ*).tw. )

S2 exp Fluid Therapy/ OR exp Body Fluids/ OR fluid*.tw. OR ( solutions/ or exp hypertonic solutions/ or isotonic solutions/ or rehydration solutions/ ) OR solution*.tw. OR ( (rehydrat ${ }^{\star}$ or dehydrat* or hydrat*).tw. ) OR Sodium Chloride/ OR ( (saline* or sodium).tw,nm ) OR hyponatr*.tw. OR exp Infusions, Parenteral/ OR ( (parenteral adj2 (infusion* or solution*)).tw. ) OR Water Deprivation/

S3 starch ${ }^{\star}$ or dextran* or gelofus* or haemacc* or hemacc ${ }^{\star}$ or plasma* or albumin* or electrolyt*

\section{S4 S2 OR S13}

\section{S5 S1 AND S4}

\section{Appendix 3. CINAHL (Ebsco) Search Strategy 2016 Update}

S1 ( ( (MH "Fluid Therapy+") OR ( (MH "Body Fluids") OR (MH "Body Water") ) OR ( TI fluid* OR AB fluid* ) OR (MH "Solutions+") OR ( TI (solution* or rehydrat* or dehydrat* or hydrat*) OR AB (solution* or rehydrat* or dehydrat* or hydrat $\left.{ }^{\star}\right)$ ) OR (MH "Sodium Chloride") OR ( TI (sodium or saline $^{\star}$ ) OR AB (sodium ${ }^{\star}$ or saline ${ }^{\star}$ ) ) OR ( TI hyponatr ${ }^{\star}$ OR AB hyponatr ${ }^{\star}$ ) OR (MH "Infusions, Parenteral+") OR (MH "Parenteral Nutrition Solutions") OR (MH "Fluid-Electrolyte Balance+") OR (MH "Fluid-Electrolyte Imbalance+") ) OR ( TI electrolyt* OR AB electrolyt* ) OR (MH "Albumins+") OR (MH "Plasma+") OR (MH "Plasma Substitutes+") OR ( (plasma* or albumin* or starch* or dextran* or gelofus* or haemacc ${ }^{\star}$ or hemacc $\left.{ }^{\star}\right)$ OR AB (plasma* or albumin* or starch* or dextran ${ }^{\star}$ or gelofus* or haemacc* or hemacc $\left.\left.{ }^{\star}\right)\right)$ ) AND ( ( ( (MH "Meningitis") OR (MH "Meningitis, Bacterial+")) OR (MH "Meningococcal Infections+") OR (MH "Pneumococcal Infections+") OR (MH "Neisseria Infections") OR (MH "Escherichia Coli Infections") OR ( TI ("escherichia coli" or "e coli") OR AB ("escherichia coli" or "e coli") ) OR (MH "Listeria Infections") OR ( TI hib OR AB hib ) OR ( TI "listeria monocytogenes" OR AB "listeria monocytogenes") OR (MH "Haemophilus Infections") OR (MH "Haemophilus Influenzae") OR ( TI ((haemophilus or hemophilus) N2 (mening* or infect*)) OR AB ((haemophilus or hemophilus) N2 (mening* or infect*)) ) ) OR ( TI ("streptococcus group b" or "streptococcus agalactiae") OR AB ("streptococcus group b" or "streptococcus agalactiae") ) OR ( $\mathrm{TI}$ (meningit* or meningococc $\left.{ }^{\star}\right)$ OR AB (meningit* or meningococ $\left.{ }^{\star}\right)$ )

S2 (MH "Clinical Trials+") OR PT clinical trial OR ( TI clinical* trial* OR AB clinical* trial* ) OR ( TI ((singl* or doubl* or tripl* or trebl*) N1 (blind $^{\star}$ or mask $\left.{ }^{\star}\right)$ ) OR AB ((singl* or doubl* or tripl* or trebl*) N1 (blind* or mask $\left.{ }^{\star}\right)$ ) ) OR (MH "Random Assignment") OR ( TI random* OR AB random* ) OR (MH "Placebos") OR ( TI placebo* OR AB placebo* ) OR (MH "Quantitative Studies")

\section{S3 S1 AND S2}

S4 EM 201311-

S5 S3 AND S4

\section{Appendix 4. Global Health (Ebsco) Search Strategy 2016 Update}

S1 exp Fluid Therapy/ OR exp Body Fluids/ OR fluid ${ }^{\star}$.tw. OR ( solutions/ or exp hypertonic solutions/ or isotonic solutions/ or rehydration solutions/ ) OR solution*.tw. OR ((rehydrat* or dehydrat* or hydrat*).tw. ) OR Sodium Chloride/ OR ((saline* or sodium).tw,nm ) OR hyponatr*.tw. OR exp Infusions, Parenteral/ OR ( (parenteral adj2 (infusion* or solution*)).tw. ) OR Water Deprivation/

S2 starch* or dextran* or gelofus* or haemacc* or hemacc* or plasma* or albumin* or electrolyt* 
S3 ( Meningitis/ OR exp Meningitis, Bacterial/ OR exp Meningococcal Infections/ OR exp Pneumococcal Infections/ OR exp Neisseria meningitidis/ OR exp Escherichia coli Infections/ OR (("escherichia coli" or "e coli").tw. ) OR ( Listeria monocytogenes/ or Meningitis, Listeria/ ) OR "listeria monocytogenes".tw. OR Haemophilus influenzae type b/ OR (haemophilus infections/ or meningitis, haemophilus/) OR (((haemophilus or hemophilus or hib) adj2 (mening* or infect*)).tw.)) OR Streptococcus agalactiae/ OR (("streptococcus group b" or "streptococcus agalactiae").tw. ) OR ((meningit* or meningococ*).tw. )

\section{S4 S1 OR S2}

S5 S4 AND S3

\section{Appendix 5. Web of Science (Thomson Reuters) search strategy 2016 Update}

\#1 Topic=(meningit* ${ }^{*}$ or meningococ $\left.{ }^{\star}\right)$

\#2 Topic=(fluid* or solution* or dehydrat* or hydrat* or rehydrat* or saline* or sodium* or hyponatr* or "parenteral infusion*" or "water deprivat*" or "water restrict*" or electrolyt* or albumin* or plasma* or starch* or dextran* or gelofus* or haemacc* or hemac*)

\section{\#3 \#2 AND \#1}

\#4 Topic=(random* or placebo* or crossover ${ }^{\star}$ or "cross over" or allocat* or ((singl* or doubl*) NEAR/1 blind*)) OR Title=(trial)

\#5 \#4 AND \#3

\#6 \#5 Refined by: Publication Years=( 2013 OR 2014 OR 2015 OR 2016 )

\section{Appendix 6. MEDLINE search strategy 2014 Update}

\section{MEDLINE (Ovid)}

1 Meningitis/

2 exp Meningitis, Bacterial/

3 exp Meningococcal Infections/

4 exp Pneumococcal Infections/

$5 \exp$ Neisseria meningitidis/

6 exp Escherichia coli Infections/

7 ("escherichia coli" or "e coli").tw.

8 Listeria monocytogenes/ or Meningitis, Listeria/

9 "listeria monocytogenes".tw.

10 Haemophilus influenzae type b/

11 haemophilus infections/ or meningitis, haemophilus/

12 ((haemophilus or hemophilus or hib) adj2 (mening* or infect $\left.^{\star}\right)$ ).tw.

13 Streptococcus agalactiae/

14 ("streptococcus group b" or "streptococcus agalactiae").tw.

15 (meningit* or meningococ $\left.{ }^{\star}\right)$.tw.

16 or/1-15

17 exp Fluid Therapy/

18 exp Body Fluids/

19 fluid*. tw. $^{*}$

20 solutions/ or exp hypertonic solutions/ or isotonic solutions/ or rehydration solutions/

21 solution*.tw.

22 (rehydrat* or dehydrat* or hydrat ${ }^{\star}$ ).tw.

23 Sodium Chloride/

24 (saline $^{\star}$ or sodium*).tw,nm.

25 hyponatr*.tw.

26 exp Infusions, Parenteral/

27 (parenteral adj2 (infusion* or solution*)).tw.

28 Water Deprivation/

29 exp Water-Electrolyte Balance/

30 exp Water-Electrolyte Imbalance/

31 electrolyt ${ }^{\star} . \mathrm{tw}, \mathrm{nm}$.

32 exp Albumins/

33 albumin*.tw,nm.

34 exp Plasma/

35 exp Plasma Substitutes/

36 plasma*.tw.

Fluid therapy for acute bacterial meningitis (Review) 
37 (starch $^{\star}$ or dextran* or gelofus ${ }^{\star}$ or haemacc* or hemacc $\left.{ }^{\star}\right) . t w, n m$.

38 or/17-37

3916 and 38

\section{Appendix 7. EMBASE (Elsevier) search strategy 2014 update}

\#38 \#36 AND \#37

\#37 819074

\#37.8 \#37.3 NOT \#37.7

\#37.7 \#37.4 NOT \#37.6

\#37.6 \#37.4 AND \#37.5

\#37.5 'human'/de AND [embase]/lim

\#37.4 'animal'/de OR 'nonhuman'/de OR 'animal experiment'/de AND [embase]/lim

\#37.3\#37.1 OR \#37.2

\#37.2 random*:ab,ti OR placebo*:ab,ti OR crossover*ab,ti OR 'cross over':ab,ti OR allocat*:ab,ti OR trial:ti OR (doubl* NEXT/1 blind):ab,ti AND [embase]/lim

\#37.1 'randomized controlled trial'/exp OR 'single blind procedure'/exp OR 'double blind procedure'/exp OR 'crossover procedure'/exp AND [embase]/lim

\#36 \#16 AND \#35

\#35 \#17 OR \#18 OR \#19 OR \#20 OR \#21 OR \#22 OR \#23 OR \#24 OR \#25 OR \#26 OR \#27 OR \#28 OR \#29 OR \#30 OR \#31 OR \#32 OR \#33 OR \#34 \#34 albumin*:ab,ti OR plasma*:ab,ti OR starch*:ab,ti OR dextranti,ab OR gelofus*:ab,ti OR haemacc* OR hemacc*:ab,ti

\#33 'albumin'/de

\#32 'plasma'/de

\#31 'plasma substitute'/exp

\#30 electrolyt*:ab,ti

\#29 'electrolyte balance'/exp

\#28 'water deprivation'/de

\#27 (parenteral NEAR/2 (solution* OR infusion*)):ab,ti

\#26 'parenteral solution'/de

\#25 hyponatr*ab,ti

\#24 saline*:ab,ti OR sodium*:ab,ti

\#23 'sodium chloride'/de

\#22 solution*:ab,ti OR rehydrat*:ab,ti OR dehydrat*:ab,ti OR hydrat*:ab,ti

\#21 'oral rehydration solution'/de

\#20 'solution and solubility'/exp

\#19 fluid*:ab,ti

\#18 'body fluid'/de OR 'cerebrospinal fluid'/de

$\# 17$ 'fluid therapy'/exp

\#16 \#1 OR \#2 OR \#3 OR \#4 OR \#5 OR \#6 OR \#7 OR \#8 OR \#9 OR \#10 OR \#11 OR \#12 OR \#13 OR \#14 OR \#15

\#15 meningit*:ab,ti OR meningococ*:ab,ti

\#14 'streptococcus group b':ab,ti OR 'streptococcus agalactiae':ab,ti

\#13 'streptococcus agalactiae'/de

\#12 ((haemophilus OR hemophilus OR hib) NEAR/2 (mening* OR infect*)):ab,ti

\#11 'haemophilus infection'/de OR 'haemophilus meningitis'/de

\#10 'haemophilus influenzae type b'/de

\#9 'listeria monocytogenes':ab,ti

\#8 'listeria monocytogenes'/de OR 'listeriosis'/de

$\# 7$ 'escherichia coli':ab,ti OR 'e coli':ab,ti

\#6 'escherichia coli infection'/exp

\#5 'neisseria meningitidis'/de

\#4 'pneumococcal infection'/de OR 'pneumococcal meningitis'/de

\#3 'meningococcosis'/exp

\#2 'bacterial meningitis'/de OR 'group b streptococcal meningitis'/de OR 'haemophilus meningitis'/de OR 'pneumococcal meningitis'/de \#1 'meningitis'/de

\section{Appendix 8. CINAHL (Ebsco) search strategy 2014 update}

S46 S45 AND EM 201006-

S45 S34 AND S44

S44 S35 OR S36 OR S37 OR S38 OR S39 OR S40 OR S41 OR S42 OR S43

S43 (MH "Quantitative Studies")

S42 TI placebo* OR AB placebo*

S41 (MH "Placebos") 
S40 TI random* OR AB random*

S39 (MH "Random Assignment")

S38 TI ((singl* or doubl* or tripl* or trebl*) N1 (blind* or mask $\left.\left.{ }^{\star}\right)\right)$ OR AB ((singl* or doubl* or tripl* or trebl*) N1 (blind* or mask*))

S37 $\mathrm{TI}_{\text {clinical }}{ }^{\text {trial }}{ }^{\star}$ OR AB clinical ${ }^{*}$ trial $^{\star}$

S36 PT clinical trial

S35 (MH "Clinical Trials+")

S34 S15 AND S33 S

S33 S16 OR S 17 OR S 18 OR S 19 OR S20 OR S21 OR S22 OR S23 OR S24 OR S25 OR S26 OR S27 OR S28 OR S29 OR S30 OR S 31 OR S 32

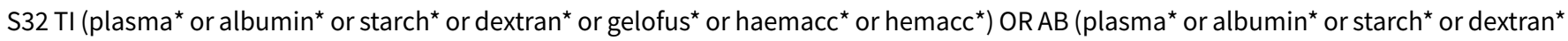
or gelofus ${ }^{\star}$ or haemacc ${ }^{\star}$ or hemacc ${ }^{\star}$ )

S31 (MH "Plasma Substitutes+")

S30 (MH "Plasma+")

S29 (MH "Albumins+")

S28 TI electrolyt* OR AB electrolyt*

S27 (MH "Fluid-Electrolyte Imbalance+")

S26 (MH "Fluid-Electrolyte Balance+")

S25 (MH "Parenteral Nutrition Solutions")

S24 (MH "Infusions, Parenteral+")

S23 TI hyponatr* OR AB hyponatr*

S22 TI (sodium* or saline ${ }^{\star}$ ) OR AB (sodium* or saline ${ }^{\star}$ )

S21 (MH "Sodium Chloride")

S20 TI (solution* or rehydrat ${ }^{\star}$ or dehydrat ${ }^{\star}$ or hydrat ${ }^{\star}$ ) OR AB (solution* or rehydrat ${ }^{\star}$ or dehydrat ${ }^{\star}$ or hydrat $^{\star}$ )

S19 (MH "Solutions+")

S18 TI fluid* OR AB fluid*

S17 (MH "Body Fluids") OR (MH "Body Water")

S16 (MH "Fluid Therapy+")

S15 S1 OR S2 OR S3 OR S4 OR S5 OR S6 OR S7 OR S8 OR S9 OR S10 OR S11 OR S12 OR S13 OR S14

$\mathrm{S} 14 \mathrm{TI}$ (meningit ${ }^{\star}$ or meningococc $\left.{ }^{\star}\right)$ OR AB (meningit* or meningococ ${ }^{\star}$ )

S13 TI ("streptococcus group b" or "streptococcus agalactiae") OR AB ("streptococcus group b" or "streptococcus agalactiae")

S12 TI hib OR AB hib

S11 TI ((haemophilus or hemophilus) N2 (mening* or infect*)) OR AB ((haemophilus or hemophilus) N2 (mening* or infect*))

S10 (MH "Haemophilus Influenzae")

S9 (MH "Haemophilus Infections")

S8 TI "listeria monocytogenes" OR AB "listeria monocytogenes"

S7 (MH "Listeria Infections")

S6 TI ("escherichia coli" or "e coli") OR AB ("escherichia coli" or "e coli")

S5 (MH "Escherichia Coli Infections")

S4 (MH "Neisseria Infections")

S3 (MH "Pneumococcal Infections+")

S2 (MH "Meningococcal Infections+")

S1 (MH "Meningitis") OR (MH "Meningitis, Bacterial+")

\section{Appendix 9. LILACS (BIREME) search strategy 2014 update}

(mh:meningitis OR meningit* OR mh:c10.228.228.507* OR mh:c10.228.566* OR mh:"Meningococcal Infections" OR mh:c01.252.400.625.549* OR meningococ ${ }^{\star}$ OR mh:"Pneumococcal Infections" OR mh:c01.252.410.890.670* OR "Infecciones Neumocócicas" OR "Infecções Pneumocócicas" OR "Streptococcus pneumoniae Infections" OR mh:"Neisseria meningitidis" OR mh:b03.440.400.425.550.550.641* OR mh:b03.660.075.525.520.500* OR mh:"Escherichia coli Infections" OR "Escherichia coli" OR "e coli" OR mh:"Listeria monocytogenes" OR mh:"Meningitis, Listeria" OR "listeria monocytogenes" OR mh:"Haemophilus influenzae type b" OR "Haemophilus influenzae type b" OR hib OR mh:"Haemophilus Infections" OR "hemophilus infections" OR "haemophilus infections" OR "Infecciones por Haemophilus" OR "Infecções por Haemophilus" OR mh:"Streptococcus agalactiae" OR "Streptococcus Group B") AND (mh:"Fluid Therapy" OR mh:e02.319.360^ OR fluidoterapia OR hidratação OR rehydrat* OR hydrat* OR dehydrat* OR "Terapia con Líquidos" OR rehidratación OR reidratação OR mh:"Body Fluids" OR fluid* OR "Líquidos Corporales" OR "Líquidos Corporais" OR mh:solutions OR solution* OR soluciones OR soluções OR mh:"Hypertonic Solutions" OR mh:"isotonic solutions" OR mh:"rehydration solutions" OR mh:"Sodium Chloride" OR saline* OR sodium* OR hyponatr* OR hiponatremia OR mh:"Infusions, Parenteral" OR mh:e02.319.267.510* OR "Infusiones Parenterales" OR "Infusões Parenterais" OR "Parenteral Infusions" OR mh:"Water Deprivation" OR "Privación de Agua" OR "Privação de Água" OR mh:"Water-Electrolyte Balance" OR "Equilibrio Hidroelectrolítico" OR "Equilíbrio Hidroeletrolítico" OR mh:g02.111.917* OR mh:g03.960* OR mh:g07.700.360.888* OR "Balance Hidroelectrolítico" OR "Equilibrio Líquido" OR osmorregulación OR "Equilíbrio Hidreletrolítico" OR "Balanço Hidroeletrolítico" OR "Balanço Hidreletrolítico" OR "Balanço Líquido" OR "Regulação Osmótica" OR mh:"Water-Electrolyte Imbalance" OR "Desequilibrio Hidroelectrolítico" OR "Desequilíbrio Hidroeletrolítico" OR electrolyt* OR mh:albumins OR albumin* OR mh:d12.776.034^ OR mh:plasma OR plasma OR mh:a12.207.152.693* OR mh:a12.207.270.695* OR mh:a15.145.693* OR starch* OR dextran* OR gelofus* OR haemacc ${ }^{\star}$ OR hemacc ${ }^{\star}$ ) AND db:("LILACS") AND type_of_study:("clinical_trials") 


\section{Appendix 10. Web of Science (Thomson Reuters) search strategy 2014 update}

\begin{tabular}{|c|c|c|}
\hline \# 6 & 127 & $\begin{array}{l}\# 4 \text { AND \#3 } \\
\text { Refined by: Publication Years=( } 2010 \text { OR } 2011 \text { OR } 2012 \text { OR 2013) } \\
\text { Databases=SCI-EXPANDED, CPCI-S, CCR-EXPANDED, IC Timespan=All years }\end{array}$ \\
\hline \# 5 & 463 & $\begin{array}{l}\# 4 \text { AND \#3 } \\
\text { Databases=SCI-EXPANDED, CPCI-S, CCR-EXPANDED, IC Timespan=All years }\end{array}$ \\
\hline \# 4 & $1,416,563$ & $\begin{array}{l}\text { Topic }=\left(\text { random }^{*} \text { or placebo* or crossover }{ }^{*} \text { or "cross over" or allocat }{ }^{*} \text { or }\right. \\
\left.\left(\left(\text { singl }{ }^{*} \text { or doubl }{ }^{\star}\right) \text { NEAR/1 blind }{ }^{*}\right)\right) \text { OR Title=(trial) } \\
\text { Databases }=S C I-E X P A N D E D, C P C I-S, C C R-E X P A N D E D, I C \text { Timespan=All years }\end{array}$ \\
\hline \# 3 & 10,033 & $\begin{array}{l}\# 2 \text { AND \#1 } \\
\text { Databases=SCI-EXPANDED, CPCI-S, CCR-EXPANDED, IC Timespan=All years }\end{array}$ \\
\hline \# 2 & $4,182,944$ & 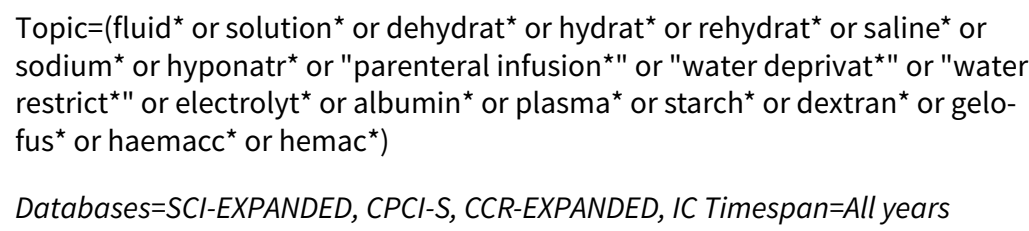 \\
\hline \# 1 & 44,766 & $\begin{array}{l}\text { Topic }=\left(\text { meningit }{ }^{\star} \text { or meningococ }{ }^{\star}\right) \\
\text { Databases }=S C I-E X P A N D E D, C P C I-S, C C R-E X P A N D E D, I C \text { Timespan=All years }\end{array}$ \\
\hline
\end{tabular}

\section{Appendix 11. Search strategy for 2010 update}

For this update we searched the Cochrane Central Register of Controlled Trials (CENTRAL) (The Cochrane Library 2010, Issue 3), which includes the Cochrane Acute Respiratory Infections Group's Specialised Register; MEDLINE (1966 to Week 4, July 2010); EMBASE (1980 to August 2010); and CINAHL (1982 to August 2010).

For the previous update in 2007 we searched the Cochrane Central Register of Controlled Trials (CENTRAL) (The Cochrane Library 2007, Issue 1) which includes the Cochrane Acute Respiratory Infections Group's Specialised Register; MEDLINE (1966 to March 2007); EMBASE (1980 to March 2007); and CINAHL (1982 to February 2007). MEDLINE, EMBASE and CINAHL were searched using OVID software. The MEDLINE search strategy is in Appendix 12.

The following search strategy was used to search MEDLINE and CENTRAL. The MEDLINE search was combined with the Cochrane Highly Sensitive Search Strategy for identifying randomised trials in MEDLINE: sensitivity- and precision-maximising version (2008 revision); Ovid format (Lefebvre 2011). The search strategy was adapted to search Embase.com (see Appendix 7) and CINAHL (see Appendix 4).

\section{MEDLINE (Ovid)}

1 exp Meningitis/

2 meningit ${ }^{\star}$. tw .

3 or $1-2$

4 exp Fluid Therapy/

5 fluid $^{\star}$.tw,nm.

6 Sodium Chloride/

7 saline ${ }^{\star}$.tw,nm.

8 Rehydration Solutions/

9 (rehydrat ${ }^{\star}$ or hydrat ${ }^{\star}$ or dehydrat*).tw.

10 exp Water-Electrolyte Balance/

11 electrolyt ${ }^{\star} . t w, n m$. 
12 (hyponatr* adj2 solution*).tw.

13 exp Albumins/

14 exp Plasma/

15 exp Plasma Substitutes/

16 albumin ${ }^{\star}$. tw.

17 plasma*.tw.

18 (starch* or dextran* or gelofus* or haemacc ${ }^{\star}$ or hemacc $\left.{ }^{\star}\right)$.tw.

19 or/4-18

203 and 19

\section{Appendix 12. MEDLINE search strategy 2008 Update}

The following search strategy was used to search MEDLINE and CENTRAL and adapted for EMBASE and CINAHL.

\section{MEDLINE (OVID)}

1 exp MENINGITIS/

2 meningit\$.mp

3 or/ $1-2$

4 exp Fluid Therapy/

5 fluid resuscitation.mp.

6 fluid restriction.mp.

7 fluid maintenance.mp.

8 fluid management.mp.

9 intravenous fluid\$.mp.

10 IV fluid\$.mp.

11 hyponatr?emic solution\$.mp.

12 exp Sodium Chloride/

13 saline.mp.

14 exp ALBUMINS/

15 exp PLASMA/

16 exp Plasma Substitutes/

17 (volume adj replac\$).mp.

18 (human adj albumin\$).mp.

19 ((frozen adj plasma) or (fresh adj plasma)).mp.

20 (plasma adj protein\$).mp.

21 (hypoalbumin $\$$ or (low adj albumin)).mp.

22 (starch or dextran\$ or gelofus\$ or haemacc\$ or hemacc\$).mp.

23 or $/ 4-22$

242 and 23

\section{FEE D B A C K}

\section{Feedback on 'Fluid therapy for acute bacterial meningitis', 13 February 2013}

\section{Summary}

In your review, you present separate analyses of 'acute severe sequelae', 'chronic severe sequelae', and 'mild to moderate sequelae' of bacterial meningitis.

I can't find anything in the review to tell me which sequelae are included under acute severe, which under chronic severe, and which under mild to moderate. The neurological sequelae described in the review seem quite severe to me: hemiparesis/hemiplegia, spasticity, seizures, visual impairment and impaired response to sound. I can't see anything that I would consider moderate but that is just my own opinion rather than being based on any external awareness of how sequelae are categorized. I also can't be sure what the different sequelae are that occur within 4 weeks (acute) and after 4 weeks (chronic) - is it the same sequelae manifesting at different times or would different sequelae appear acutely and chronically?

I think these data would be very valuable to understanding the clinical import of the different meta-analyses that you present.

I agree with the conflict of interest statement below:

I certify that I have no affiliations with or involvement in any organization or entity with a financial interest in the subject matter of my feedback.

Karen Pettersen

Affiliation: Wiley-Blackell 
Role: Editor, Cochrane Clinical Answers

\section{Reply}

The classification of acute and chronic is based on whether the sequelae effect persist after the first four weeks of illness or not, irrespective of the type of sequelae. The classification into severe and mild to moderate is as per the limited information available from the studies available and the reporting is only to aid the reader by producing such categorisation. There is no widely accepted categorisation for neurological sequelae of meningitis.

\section{Contributors}

Ian Maconochie and Soumyadeep Bhaumik

\section{WHAT'S NEW}

\begin{tabular}{lll}
\hline Date & Event & Description \\
\hline 21 March 2016 & New search has been performed & $\begin{array}{l}\text { Searches updated. We did not identify any new trials for inclu- } \\
\text { sion. We excluded three new trials (Pelkonen 2011; Roine 2014; } \\
\text { van Paridon 2015). }\end{array}$ \\
\hline 21 March 2016 & $\begin{array}{l}\text { New citation required and conclusions } \\
\text { have changed }\end{array}$ & $\begin{array}{l}\text { We reworked the GRADE profile and updated it as per current } \\
\text { Cochrane standards. The conclusion with regards to quality of } \\
\text { evidence has changed. }\end{array}$ \\
\hline
\end{tabular}

\section{H I S T ORY}

Protocol first published: Issue 2, 2004

Review first published: Issue 3, 2005

\begin{tabular}{lll}
\hline Date & Event & Description \\
\hline 5 November 2013 New search has been performed & $\begin{array}{l}\text { Seizures are captured within the primary outcome acute (short- } \\
\text { term) neurological sequelae and consequently have now been } \\
\text { removed from the list of secondary outcomes. }\end{array}$ \\
& $\begin{array}{l}\text { No new trials were included in this update. Two new trials initial- } \\
\text { ly considered were excluded (Berkley 2004; Maitland 2013). In } \\
\text { this update we have used the GRADE approach to interpret the } \\
\text { findings and these have been updated. This provides critically } \\
\text { important information for healthcare decision-making. This up- } \\
\text { date also takes into account the new MECIR standards. }\end{array}$ \\
\hline
\end{tabular}

5 November $2013 \quad \begin{aligned} & \text { New citation required but conclusions } \\ & \text { have not changed }\end{aligned}$

\begin{tabular}{lll}
\hline 14 June 2013 & Feedback has been incorporated & Feedback added. \\
\hline 9 August 2010 & New search has been performed & $\begin{array}{l}\text { Searches conducted. No new trials were included or excluded in } \\
\text { this update. }\end{array}$ \\
\hline 19 May 2008 & Amended & Converted to new review format. \\
\hline 1 March 2007 & New search has been performed & Searches conducted. \\
\hline 17 March 2005 & New search has been performed & Searches conducted. \\
\hline
\end{tabular}




\section{CONTRIBUTIONSOF AUTHORS}

Ian Maconochie (IM) jointly (with Richmal Oates-Whitehead (ROW)) conceptualised the review, commented on drafts of the protocol, was involved in selecting trials for inclusion in the review, performed independent data extraction and quality assessment of the included trials.

Soumyadeep Bhaumik (SB) led this 2016 update and was part of the 2014 update. For both updates he performed independent selection of trials for inclusion in the review, worked on the manuscript of the review. Both authors used the GRADE approach to interpret the findings of the study and commented on the drafts of the review.

\section{DECLARATIONSOF INTEREST}

Ian Maconochie - no known conflicts of interest to declare.

Soumyadeep Bhaumik - no known conflicts of interest to declare.

\section{SOURCES OF SUPPORT}

\section{Internal sources}

- Liverpool School of Tropical Medicine, UK.

- Royal College of Paediatrics and Child Health, UK.

\section{External sources}

- No sources of support supplied

\section{DIFFERENCES BETWEEN PROTOCOLANDREVIEW}

There were insufficient data to explore any of the subgroup analyses, with the exception of hypoperfusion at entry. One study subgrouped each participant group into those with hyponatraemia and those without hyponatraemia at enrolment (Singhi 1995). Therefore, we could only perform a subgroup analysis on this trial.

\section{N D EX TERMS}

\section{Medical Subject Headings (MeSH)}

Acute Disease; Developing Countries; Fluid Therapy [adverse effects] [methods] [standards]; Hyponatremia [etiology]; Meningitis, Bacterial [complications] [*therapy]; Randomized Controlled Trials as Topic

\section{MeSH check words}

Child; Humans; Infant 